\title{
The behaviour of inositol 1,3,4,5,6-pentakisphosphate in the presence of the major biological metal cations
}

\author{
Nicolás Veiga $\cdot$ Julia Torres $\cdot$ Himali Y. Godage \\ Andrew M. Riley · Sixto Domínguez • \\ Barry V. L. Potter · Alvaro Díaz · Carlos Kremer
}

Received: 9 March 2009/ Accepted: 20 April 2009/Published online: 5 May 2009

(C) SBIC 2009

\begin{abstract}
The inositol phosphates are ubiquitous metabolites in eukaryotes, of which the most abundant are inositol hexakisphosphate $\left(\operatorname{Ins} P_{6}\right)$ and inositol 1,3,4,5,6-pentakisphosphate $\left.\left[\operatorname{Ins}(1,3,4,5,6) P_{5}\right)\right]$. These two compounds, poorly understood functionally, have complicated complexation and solid formation behaviours with multivalent cations. For $\operatorname{Ins} P_{6}$, we have previously described this chemistry and its
\end{abstract}

Electronic supplementary material The online version of this article (doi:10.1007/s00775-009-0510-z) contains supplementary material, which is available to authorized users.

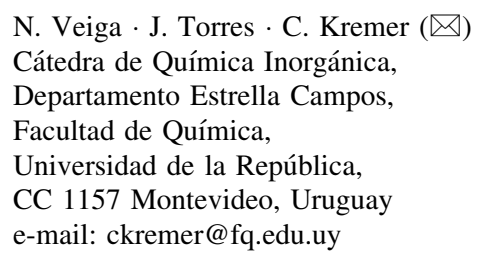

H. Y. Godage · A. M. Riley · B. V. L. Potter Wolfson Laboratory of Medicinal Chemistry, Department of Pharmacy and Pharmacology, University of Bath,

Claverton Down,

Bath BA2 7AY, UK

\section{S. Domínguez}

Departamento de Química Inorgánica,

Universidad de La Laguna,

Tenerife, Canary Islands, Spain

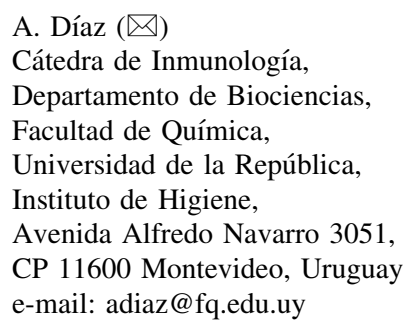

biological implications (Veiga et al. in J Inorg Biochem 100:1800, 2006; Torres et al. in J Inorg Biochem 99:828, 2005). We now cover similar ground for $\operatorname{Ins}(1,3,4,5,6) P_{5}$, describing its interactions in solution with $\mathrm{Na}^{+}, \mathrm{K}^{+}, \mathrm{Mg}^{2+}$, $\mathrm{Ca}^{2+}, \mathrm{Cu}^{2+}, \mathrm{Fe}^{2+}$ and $\mathrm{Fe}^{3+}$, and its solid-formation equilibria with $\mathrm{Ca}^{2+}$ and $\mathrm{Mg}^{2+}$. Ins(1,3,4,5,6) $P_{5}$ forms soluble complexes of 1:1 stoichiometry with all multivalent cations studied. The affinity for $\mathrm{Fe}^{3+}$ is similar to that of $\operatorname{Ins} P_{6}$ and inositol 1,2,3-trisphosphate, indicating that the 1,2,3trisphosphate motif, which $\operatorname{Ins}(1,3,4,5,6) P_{5}$ lacks, is not absolutely necessary for high-affinity $\mathrm{Fe}^{3+}$ complexation by inositol phosphates, even if it is necessary for their prevention of the Fenton reaction. With excess $\mathrm{Ca}^{2+}$ and $\mathrm{Mg}^{2+}$, Ins $(1,3,4,5,6) P_{5}$ also forms the polymetallic complexes $\left[\mathrm{M}_{4}\left(\mathrm{H}_{2} \mathrm{~L}\right)\right]$ [where $\mathrm{L}$ is fully deprotonated Ins $\left.(1,3,4,5,6) P_{5}\right]$. However, unlike $\operatorname{Ins} P_{6}, \operatorname{Ins}(1,3,4,5,6) P_{5}$ is predicted not to be fully associated with $\mathrm{Mg}^{2+}$ under simulated cytosolic/ nuclear conditions. The neutral $\mathrm{Mg}^{2+}$ and $\mathrm{Ca}^{2+}$ complexes have significant windows of solubility, but they precipitate as $\left[\mathrm{Mg}_{4}\left(\mathrm{H}_{2} \mathrm{~L}\right)\right] \cdot 23 \mathrm{H}_{2} \mathrm{O}$ or $\left[\mathrm{Ca}_{4}\left(\mathrm{H}_{2} \mathrm{~L}\right)\right] \cdot 16 \mathrm{H}_{2} \mathrm{O}$ whenever they exceed 135 and $56 \mu \mathrm{M}$ in concentration, respectively. Nonetheless, the low stability of the $\left[\mathrm{M}_{4}\left(\mathrm{H}_{2} \mathrm{~L}\right)\right]$ complexes means that the $1: 1$ species contribute to the overall solubility of Ins $(1,3,4,5,6) P_{5}$ even under significant $\mathrm{Mg}^{2+}$ or $\mathrm{Ca}^{2+}$ excesses. We summarize the solubility behaviour of Ins $(1,3,4,5,6) P_{5}$ in straightforward plots.

Keywords Inositol - Inositol polyphosphates · Iron $\cdot$ Calcium $\cdot$ Magnesium

\section{Introduction}

The myo-inositol phosphates (Ins $P$ s) form a broad panel of eukaryotic-specific signalling metabolites that, except for 


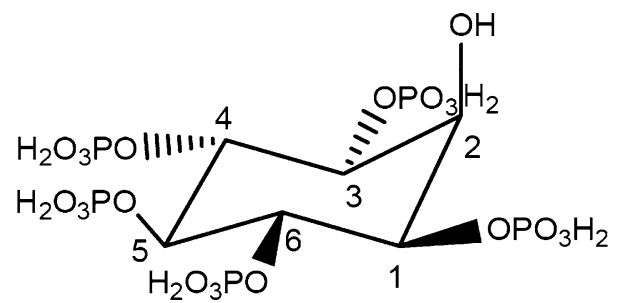

Fig. 1 Structure of inositol 1,3,4,5,6-pentakisphosphate $\left[\operatorname{Ins}(1,3,4,5,6) P_{5}\right]$ presented in the thermodynamically more stable five-equatorial, one-axial conformation. Note that the axial hydroxyl is also the one that is not forming a phosphate ester

inositol 1,4,5-trisphosphate, are still poorly understood (reviewed in [1]). Together with inositol hexakisphosphate (Ins $P_{6}$ ), inositol 1,3,4,5,6-pentakisphosphate $\left[\operatorname{Ins}(1,3,4,5,6) P_{5}\right.$, Fig. 1] is the most abundant member of the family [2-5]. $\operatorname{Ins}(1,3,4,5,6) P_{5}$ is the metabolic precursor of Ins $P_{6}[6]$, and both $\operatorname{Ins}(1,3,4,5,6) P_{5}$ and $\operatorname{Ins} P_{6}$ are precursors of inositol pyrophosphates (reviewed in [7]). Mice that lack the enzyme responsible for the synthesis of Ins $(1,3,4,5,6) P_{5}$ die during embryonic development, indicating an essential role for this compound and/or its derived metabolites [8]. However, the function of $\operatorname{Ins}(1,3,4,5,6) P_{5}$ is not yet clear. Ins $(1,3,4,5,6) P_{5}$, as well as other higher Ins $P$ s, can clearly bind to pleckstrin homology (PH) domains, thus competitively inhibiting their interactions with phosphoinositide headgroups [9]. Although in most in vitro assays various higher Ins $P$ s will act on a given $\mathrm{PH}$-domain-containing protein, the discovery that the "minor" isomer inositol 1,2,3,5,6-pentakisphosphate is the specific ligand of pleckstrin gives credence to the idea that in vivo specific Ins $P$ s target specific $\mathrm{PH}$ domains [10]. However, no interaction with a PH domain that is clearly specific to Ins $(1,3,4,5,6) P_{5}$ has been reported to date. An apparently specific activity of $\operatorname{Ins}(1,3,4,5,6) P_{5}$ has been uncovered in the $\mathrm{Wnt} / \beta$-catenin pathway, in which the compound accumulates in response to Wnt $3 \mathrm{a}$ and mediates the stabilization of $\beta$-catenin [11]; the direct protein target of $\operatorname{Ins}(1,3,4,5,6) P_{5}$ in this pathway is not known. Meanwhile, $\operatorname{Ins}(1,3,4,5,6) P_{5}$ fulfils what is probably a different function altogether in certain non-mammalian erythrocytes that contain very high concentrations of the compound (reviewed in [1]).

Elucidation of the biological roles of the higher Ins $P$ s has been complicated by their intricate structural and metabolic interrelatedness. This has been aggravated by the unusual and often non-intuitive behaviour displayed by these highly charged compounds, in particular in the presence of multivalent cations. This behaviour can be the source of many artefacts (reviewed in [12]). For $\operatorname{Ins} P_{6}$, we have over the past few years strived to make a rigorous and at the same time "biological-user-friendly" description of its chemistry with multivalent cations [13-15]. We have also studied the chemistry of inositol 1,2,3-trisphosphate
[Ins $\left.(1,2,3) P_{3}\right]$, focusing on the likelihood of its proposed interaction with $\mathrm{Fe}^{3+}$ in the cellular context [16]. In the present paper we study $\operatorname{Ins}(1,3,4,5,6) P_{5}$, focusing on its interactions with $\mathrm{Na}^{+}, \mathrm{K}^{+}, \mathrm{Ca}^{2+}, \mathrm{Mg}^{2+}, \mathrm{Cu}^{2+}, \mathrm{Fe}^{2+}$ and $\mathrm{Fe}^{3+}$ in solution, and its solid-formation equilibria with $\mathrm{Ca}^{2+}$ and $\mathrm{Mg}^{2+}$. Our results predict that $\operatorname{Ins}(1,3,4,5,6) P_{5}$ does not have a high enough affinity for $\mathrm{Mg}^{2+}$ to be fully associated with this cation under cytosolic and nuclear conditions. They also predict that the compound would be fully soluble under those conditions, and that it even has a significant window of solubility under calcium-rich conditions such as those of the extracellular medium. We have summarized the non-intuitive solubility behaviour of Ins $(1,3,4,5,6) P_{5}$ in straightforward plots that should be of help when planning experiments with this compound.

\section{Materials and methods}

\section{Chemicals}

All common laboratory chemicals were of reagent grade, purchased from commercial sources and used without further purification. $\mathrm{NaCl}, \mathrm{KCl}, \mathrm{CaCl}_{2} \cdot 2 \mathrm{H}_{2} \mathrm{O}, \mathrm{MgCl}_{2} \cdot 6 \mathrm{H}_{2} \mathrm{O}$, $\mathrm{CuSO}_{4} \cdot 5 \mathrm{H}_{2} \mathrm{O},\left(\mathrm{NH}_{4}\right)_{2} \mathrm{Fe}\left(\mathrm{SO}_{4}\right)_{2} \cdot 6 \mathrm{H}_{2} \mathrm{O}$, and $\mathrm{Fe}\left(\mathrm{ClO}_{4}\right)_{3} \cdot x \mathrm{H}_{2} \mathrm{O}$ were used as metal sources. Solutions of the metals were standardized according to standard techniques [17]. Ins $(1,3,4,5,6) P_{5}$ was obtained from myo-inositol in $86 \%$ isolated overall yield over five steps. Briefly, transesterification of myo-inositol with trimethyl orthobenzoate in the presence of an acid catalyst followed by acid hydrolysis of the product, myo-inositol 1,3,5-orthobenzoate, gave 2-O-benzoyl myo-inositol, which was then phosphorylated. Deprotection of the fully protected pentakisphosphate followed by the removal of the benzoate ester in concentrated aqueous ammonia afforded $\operatorname{Ins}(1,3,4,5,6) P_{5}$ as the hexaammonium salt, $\left(\mathrm{NH}_{4}\right)_{6} \mathrm{H}_{4} \mathrm{~L}$, which was verified by elemental analysis [Anal. calc. (\%) for $\mathrm{C}_{6} \mathrm{H}_{35} \mathrm{P}_{5} \mathrm{O}_{21} \mathrm{~N}_{6}$ : $\mathrm{C} 10.6, \mathrm{H}$ 5.2, N 12.3. Found (\%): C 10.3, H 5.4, N 12.4.] to conform to the previous formula [18]. Solutions of Ins $(1,3,4,5,6) P_{5}$ were prepared by weighing this hexaammonium salt $\left(\mathrm{NH}_{4}\right)_{6} \mathrm{H}_{4} \mathrm{~L}$. The standard $\mathrm{HCl}$ solutions were prepared from Merck standard ampoules. The titrant solution $\left[0.1 \mathrm{M}\right.$ solution of $\mathrm{Me}_{4} \mathrm{~N}(\mathrm{OH})$ in $0.15 \mathrm{M}$ $\left.\mathrm{Me}_{4} \mathrm{NCl}\right]$ was prepared by dissolving $\mathrm{Me}_{4} \mathrm{~N}(\mathrm{OH})$. $5 \mathrm{H}_{2} \mathrm{O}$ (Fluka), and was standardized with potassium biphthalate.

IR spectroscopy, elemental analysis and thermal analysis

IR spectroscopy was carried out with a Bomen Fourier transform IR spectrophotometer, with samples present as 
$1 \% \mathrm{KBr}$ pellets. Elemental analysis $(\mathrm{C}, \mathrm{H})$ was performed using a Carlo Erba EA 1108 instrument. The cacium content in the solid samples was determined gravimetrically as previously described [13]. Magnesium was determined volumetrically according to standard techniques [17]. Thermal analysis was performed with a Shimadzu DTA-50, TGA-50 instrument with a TA 50I interface, using a platinum cell and nitrogen atmosphere. Experimental conditions were $1{ }^{\circ} \mathrm{C} \mathrm{min}{ }^{-1}$ temperature ramp rate and $50 \mathrm{~mL} \mathrm{~min}^{-1}$ nitrogen flow rate.

\section{Potentiometric measurements}

All solutions were freed of carbon dioxide by argon bubbling. The protonation constants of $\operatorname{Ins}(1,3,4,5,6) P_{5}$ were determined at $37.0{ }^{\circ} \mathrm{C}, 0.15 \mathrm{M}$ ionic strength in the noninteracting electrolyte $\mathrm{Me}_{4} \mathrm{NCl}$. Five potentiometric titrations, comprising about 150 experimental points each, were carried out in the $\operatorname{Ins}(1,3,4,5,6) P_{5}$ concentration interval 0.5-3 mM, covering pH values between 2 and 11 .

Since an ammonium salt was used as the Ins $(1,3,4,5,6) P_{5}$ source, the (weak) acidity of the ammonium ion had to be taken into account when the desired constants were calculated. Thus, the acid dissociation constant of ammonium was determined de novo under the conditions of the study, through three potentiometric titrations using $\mathrm{NH}_{4} \mathrm{Cl}$. The hydrolysis constants of $\mathrm{Fe}(\mathrm{III})$ under the same conditions were taken from data previously reported [14].

Then the behaviour of $\operatorname{Ins}(1,3,4,5,6) P_{5}$ in the presence of $\mathrm{Na}^{+}, \mathrm{K}^{+}, \mathrm{Ca}^{2+}, \mathrm{Mg}^{2+}, \mathrm{Cu}^{2+}, \mathrm{Fe}^{2+}$ and $\mathrm{Fe}^{3+}$ ions was analysed, also in $0.15 \mathrm{M} \mathrm{Me}_{4} \mathrm{NCl}$ and at $37.0{ }^{\circ} \mathrm{C}$. Three to eight potentiometric titrations were carried out for each cation (about 150 experimental points for each titration), at metal ion concentrations ranging from 1 to $50 \mathrm{mM}$ (for alkali metal ions) or 0.5 to $3 \mathrm{mM}$ (for alkaline earth and transition metal ions), and $\operatorname{Ins}(1,3,4,5,6) P_{5}$ to metal molar ratios from 0.01 to 2 (for alkali metal ions) and from 0.2 to 3 (for alkaline earth and transition metal ions). Owing to the lower affinity towards $\operatorname{Ins}(1,3,4,5,6) P_{5}$ expected for $\mathrm{M}^{+}$ cations in comparison with $\mathrm{M}^{2+}$ or $\mathrm{M}^{3+}$, higher absolute concentrations of metal ions and lower Ins $(1,3,4,5,6) P_{5}$ to metal molar ratios were used in the former cases. Potentiometric titrations were carried out as previously described [14], $I$ being adjusted by addition of $\mathrm{Me}_{4} \mathrm{NCl}$.

The cell constants, $E^{\circ}$, and the liquid junction potentials were determined under the same conditions using the computer program GLEE [19]. The data obtained were analysed using the HYPERQUAD program [20]. In all cases, the fit of the values predicted by the model to the experimental data was estimated on the basis of the parameter $\sigma$ corresponding to the scaled sum of square differences between predicted and experimental values.
Then, the constants were used to produce species distribution diagrams using the HySS program [21].

Synthesis of $\left[\mathrm{Mg}_{4}\left(\mathrm{H}_{2} \mathrm{~L}\right)\right] \cdot 23 \mathrm{H}_{2} \mathrm{O}$ and

$\left[\mathrm{Ca}_{4}\left(\mathrm{H}_{2} \mathrm{~L}\right)\right] \cdot 16 \mathrm{H}_{2} \mathrm{O}$

An $8.8 \mathrm{mM}$ aqueous solution of $\operatorname{Ins}(1,3,4,5,6) P_{5}$ was prepared, and the $\mathrm{pH}$ was adjusted to $10-11$ by addition of $1 \mathrm{M} \mathrm{LiOH}$. To $5 \mathrm{~mL}(0.044 \mathrm{mmol})$ of this solution, $36.0 \mathrm{mg}$ of $\mathrm{MgCl}_{2} \cdot 6 \mathrm{H}_{2} \mathrm{O}(0.18 \mathrm{mmol})$ dissolved in the minimum amount of water was added. A white solid immediately appeared, and was separated by centrifugation, washed with water $(2 \times 5 \mathrm{~mL})$, and dried with ethanol $(1 \times 5 \mathrm{~mL})$. The preparation of $\left[\mathrm{Ca}_{4}\left(\mathrm{H}_{2} \mathrm{~L}\right)\right]$. $16 \mathrm{H}_{2} \mathrm{O}$ followed a similar procedure, starting from $26.0 \mathrm{mg}$ of $\mathrm{CaCl}_{2} \cdot 2 \mathrm{H}_{2} \mathrm{O}(0.18 \mathrm{mmol})$ as the metal source. The yield was $63 \%$ for $\left[\mathrm{Mg}_{4}\left(\mathrm{H}_{2} \mathrm{~L}\right)\right] \cdot 23 \mathrm{H}_{2} \mathrm{O}$ and $56 \%$ for $\left[\mathrm{Ca}_{4}\left(\mathrm{H}_{2} \mathrm{~L}\right)\right] \cdot 16 \mathrm{H}_{2} \mathrm{O}$. Anal. Calc. for $\mathrm{Mg}_{4} \mathrm{C}_{6} \mathrm{H}_{55} \mathrm{O}_{44} \mathrm{P}_{5}$ : C 6.7, $\mathrm{H} \mathrm{5.1,} \mathrm{Mg}$ 9.0\%. Found: C 6.3, H 5.0, Mg 9.5\%. Anal. Calc. for $\mathrm{Ca}_{4} \mathrm{C}_{6} \mathrm{H}_{41} \mathrm{O}_{37} \mathrm{P}_{5}$ : C 7.1, H 4.1, Ca $15.7 \%$. Found: $\mathrm{C}$ 6.8, $\mathrm{H} 4.0$, $\mathrm{Ca} 15.2 \%$. The thermal analysis agreed with the proposed formula: $38.4 \%$ weight loss for $\left[\mathrm{Mg}_{4}\left(\mathrm{H}_{2} \mathrm{~L}\right)\right] \cdot 23 \mathrm{H}_{2} \mathrm{O}$ and $28.1 \%$ weight loss for $\left[\mathrm{Ca}_{4}\left(\mathrm{H}_{2} \mathrm{~L}\right)\right] \cdot 16 \mathrm{H}_{2} \mathrm{O}$, corresponding to the elimination of water, compared with calculated values of $38.2 \%$ for $\left[\mathrm{Mg}_{4}\left(\mathrm{H}_{2} \mathrm{~L}\right)\right] \cdot 23 \mathrm{H}_{2} \mathrm{O}$ and $28.2 \%$ for $\left[\mathrm{Ca}_{4}\left(\mathrm{H}_{2} \mathrm{~L}\right)\right] \cdot 16 \mathrm{H}_{2} \mathrm{O}$.

\section{Solubility measurements}

Solubility measurements were carried out at constant ionic strength, $I=0.15 \mathrm{M} \mathrm{Me}{ }_{4} \mathrm{NCl}$, and $37.0{ }^{\circ} \mathrm{C}$. An amount of $10-40 \mathrm{mg}$ of the compound- $\left[\mathrm{Mg}_{4}\left(\mathrm{H}_{2} \mathrm{~L}\right)\right] \cdot 23 \mathrm{H}_{2} \mathrm{O}$ or $\left.\left[\mathrm{Ca}_{4}\left(\mathrm{H}_{2} \mathrm{~L}\right)\right] \cdot 16 \mathrm{H}_{2} \mathrm{O}\right)$ - was suspended in $10.0 \mathrm{~mL}$ of $0.15 \mathrm{M}$ aqueous $\mathrm{Me}_{4} \mathrm{NCl}$ at $37.0{ }^{\circ} \mathrm{C}$. Known amounts of $\mathrm{HCl}$ were added, so as to reach equilibrium points corresponding to measurable amounts of metal ion in solution. Each mixture was kept in a glass jacketed cell under continuous stirring until the measured $\mathrm{pH}$ was constant (about 1 week). After the equilibrium had been reached, the solid in excess was filtered out (Macherey-Nagel MN $640 \mathrm{~m}$ paper), and the total metal ion concentration was determined in the supernatant. Total calcium and magnesium contents were determined volumetrically according to standard techniques [17]. With these $\mathrm{M}$ (II) concentration values, and with the assumption of a 4:1:2 stoichiometry [M(II)/Ins(1,3,4,5,6) $P_{5} / \mathrm{H}^{+}$], total amounts of $\operatorname{Ins}(1,3,4,5,6) P_{5}$ in the solution were calculated. Then total concentrations of $\mathrm{M}(\mathrm{II})$, Ins $(1,3,4,5,6) P_{5}$ and $\mathrm{H}^{+}$were used as inputs for the HySS program [21] to determine the equilibrium concentrations of (free) $\mathrm{M}^{2+}$ and $\mathrm{H}_{2} \mathrm{~L}^{8-}$, which define the $K_{\mathrm{s} 0}$. In this calculation, the complete set of solution equilibria previously measured were taken into account. At least three independent determinations were performed for each metal ion. 


\section{Results and discussion}

Protonation equilibria of $\operatorname{Ins}(1,3,4,5,6) P_{5}$

Ins $(1,3,4,5,6) P_{5}$ can be considered as a polyprotic acid containing ten protons, $\mathrm{H}_{10} \mathrm{~L}$. The values for the corresponding deprotonation/protonation equilibrium constants, which are needed for studying the metal complexation reactions, are presented in Table 1 . We were able to detect the first seven of these protonation reactions, the last three not being amenable to our methods, owing to the strong acidity of the species $\mathrm{H}_{10} \mathrm{~L}, \mathrm{H}_{9} \mathrm{~L}^{-}$and $\mathrm{H}_{8} \mathrm{~L}^{2-}$ (which should have $\mathrm{p} K_{\mathrm{a}}$ values smaller than 1.1). The $\log \beta$ values determined followed the expected order and are consistent with values in a previous report [22] (in which only five protonation constants that had measured by potentiometry, in $0.2 \mathrm{M} \mathrm{KCl}$ and at $37.0^{\circ} \mathrm{C}$, were reported). A species distribution diagram for $\operatorname{Ins}(1,3,4,5,6) P_{5}$ in the absence of metal ions is shown in Fig. 2. For neutral $\mathrm{pH}$ values, the predominant species are $\mathrm{H}_{4} \mathrm{~L}^{6-}$ and $\mathrm{H}_{3} \mathrm{~L}^{7-}$.

Interactions between $\operatorname{Ins}(1,3,4,5,6) P_{5}$ and alkali metal ions

Although the interactions with the alkali metal ions are expected to be very weak, it is important to describe them, as either $\mathrm{Na}^{+}$or $\mathrm{K}^{+}$cations are present in biological media in a large excess with respect to $\operatorname{Ins}(1,3,4,5,6) P_{5}$. The stability constants for the $\mathrm{Na}(\mathrm{I})-\operatorname{Ins}(1,3,4,5,6) P_{5}$ and $\mathrm{K}(\mathrm{I})-$ Ins $(1,3,4,5,6) P_{5}$ species (Table 2$)$, although exceptionally high for complexes involving alkali metal ions, are not high in absolute terms. Figure 3 shows species distribution diagrams for $1 \mathrm{mM} \operatorname{Ins}(1,3,4,5,6) P_{5}$ in the presence of 100 fold excess $\mathrm{K}^{+}$(a similar graph for $\mathrm{Na}^{+}$is presented in Fig. S1). Under these conditions (which are close to those of part of the experimental titrations), metal-containing species

Table 1 Logarithms of the overall protonation constants of inositol 1,3,4,5,6-pentakisphosphate $\left[\operatorname{Ins}(1,3,4,5,6) P_{5}\right]$ in $0.15 \mathrm{M} \mathrm{Me}_{4} \mathrm{NCl}$ at $37.0{ }^{\circ} \mathrm{C} ; \sigma=0.9$

\begin{tabular}{lr}
\hline Equilibrium & $\log \beta$ \\
\hline $\mathrm{L}^{10-}+\mathrm{H}^{+} \rightarrow \mathrm{HL}^{9-}$ & $11.62(5)$ \\
$\mathrm{L}^{10-}+2 \mathrm{H}^{+} \rightarrow \mathrm{H}_{2} \mathrm{~L}^{8-}$ & $23.02(3)$ \\
$\mathrm{L}^{10-}+3 \mathrm{H}^{+} \rightarrow \mathrm{H}_{3} \mathrm{~L}^{7-}$ & $32.39(7)$ \\
$\mathrm{L}^{10-}+4 \mathrm{H}^{+} \rightarrow \mathrm{H}_{4} \mathrm{~L}^{6-}$ & $39.81(7)$ \\
$\mathrm{L}^{10-}+5 \mathrm{H}^{+} \rightarrow \mathrm{H}_{5} \mathrm{~L}^{5-}$ & $45.2(1)$ \\
$\mathrm{L}^{10-}+6 \mathrm{H}^{+} \rightarrow \mathrm{H}_{6} \mathrm{~L}^{4-}$ & $47.8(1)$ \\
$\mathrm{L}^{10-}+7 \mathrm{H}^{+} \rightarrow \mathrm{H}_{7} \mathrm{~L}^{3-}$ & $48.9(2)$
\end{tabular}

The ammonium acidity constant $\left[\mathrm{NH}_{4}^{+} \rightarrow \mathrm{NH}_{3}+\mathrm{H}^{+}, \log K=\right.$ -8.854(5), $\sigma=0.4]$ and ammonium-Ins $(1,3,4,5,6) P_{5}$ interaction constants were also measured (Table 2) and taken into account to calculate the values shown

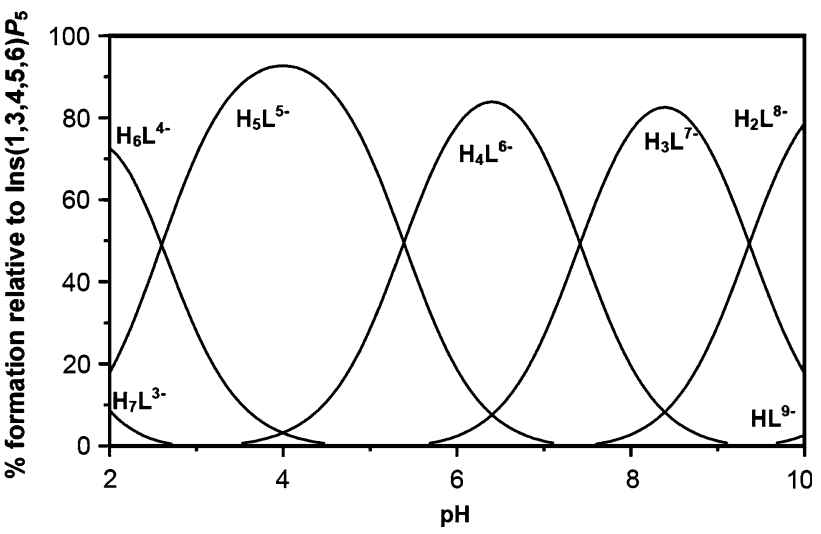

Fig. 2 Species distribution diagram for $1 \mathrm{mM} \operatorname{Ins}(1,3,4,5,6) P_{5}$, in $0.15 \mathrm{M} \mathrm{Me}_{4} \mathrm{NCl}$, at $37.0{ }^{\circ} \mathrm{C}$

become detectable only above $\mathrm{pH}$ 7. In contrast, for $1 \mathrm{mM}$ Ins $(1,3,4,5,6) P_{5}$ and $1 \mathrm{mM} \mathrm{M}^{+}$, the percentage of the ligand associated to either ion is negligible (speciation plots not shown). The comparison between $\mathrm{Na}^{+}$and $\mathrm{K}^{+}$, in terms of the formation constants (Table 2) or of species distribution diagrams (Figs. 3 and $\mathrm{S} 1$ ), shows that $\operatorname{Ins}(1,3,4,5,6) P_{5}$ interacts with these two ions in very similar ways.

Interactions in solution between $\operatorname{Ins}(1,3,4,5,6) P_{5}$ and divalent ions and $\mathrm{Fe}^{3+}$

Table 2 lists the equilibrium constants for the interactions of $\operatorname{Ins}(1,3,4,5,6) P_{5}$ with divalent cations in $0.15 \mathrm{M}$ $\mathrm{Me}_{4} \mathrm{NCl}$. The high charge displayed by $\operatorname{Ins}(1,3,4,5,6) P_{5}$

Table 2 Logarithms of the overall formation constants for complexes between $\operatorname{Ins}(1,3,4,5,6) P_{5}$ and metal ions in $0.15 \mathrm{M} \mathrm{Me}_{4} \mathrm{NCl}$ at $37.0^{\circ} \mathrm{C}$

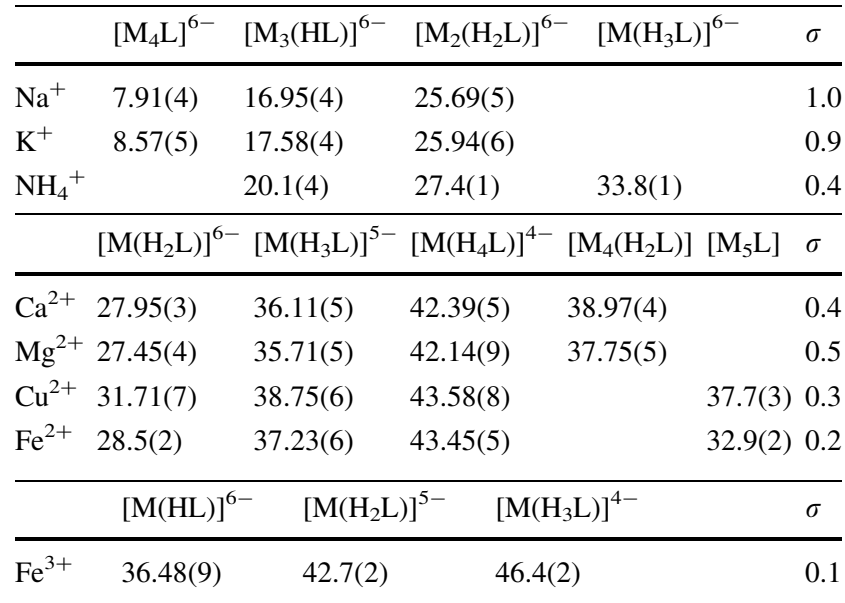

The logarithms of the ammonium acidity constant $\left[\mathrm{NH}_{4}^{+} \rightarrow\right.$ $\left.\mathrm{NH}_{3}+\mathrm{H}^{+}, \log K=-8.854(5), \sigma=0.4\right]$ as well of those of the constants describing the ammonium-Ins $(1,3,4,5,6) P_{5}$ interaction in $0.15 \mathrm{M} \mathrm{Me}_{4} \mathrm{NCl}$ at $37.0{ }^{\circ} \mathrm{C}$ (shown in the table) were also measured, and both were taken into account to calculate the remaining values shown 


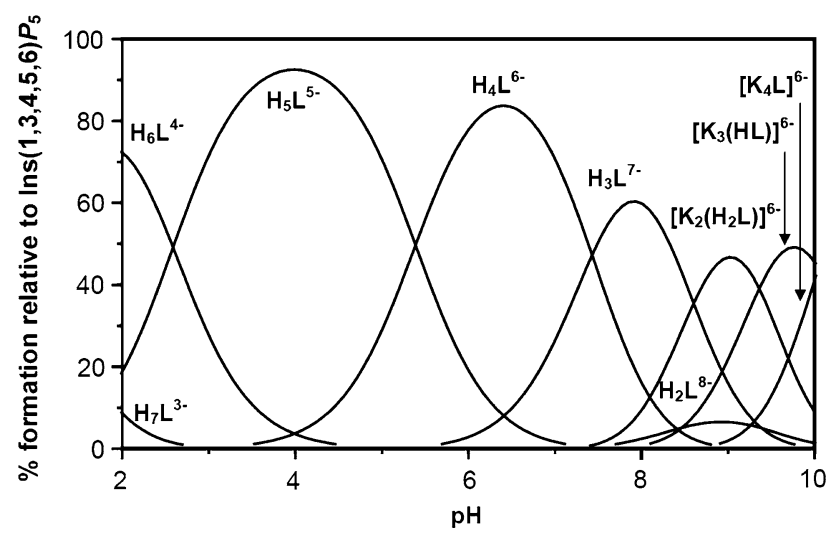

Fig. 3 Species distribution diagrams for $1 \mathrm{mM} \operatorname{Ins}(1,3,4,5,6) P_{5}$ in the presence of $\mathrm{K}^{+}$excess $(100 \mathrm{mM})$, in $0.15 \mathrm{M} \mathrm{Me}_{4} \mathrm{NCl}$, at $37.0{ }^{\circ} \mathrm{C}$

species in the absence of interacting cations (Fig. 2) indicates that strong electrostatically driven interactions with divalent cations must be expected; this is confirmed by the values of the stability constants. In addition to species with ligand-to-metal 1:1 stoichiometry, which were observed throughout the $\mathrm{pH}$ range studied, the neutral complexes $\left[\mathrm{M}_{4}\left(\mathrm{H}_{2} \mathrm{~L}\right)\right]$ and $\left[\mathrm{M}_{5} \mathrm{~L}\right]$ were detected, for alkaline earth and transition metal ions, respectively. Figure $4 \mathrm{a}$ shows the species distribution diagram for $\mathrm{Ca}^{2+}$, with $1 \mathrm{mM}$ Ins $(1,3,4,5,6) P_{5}$ and $1 \mathrm{mM} \mathrm{Ca}^{2+}$. At $\mathrm{pH}$ values around 7.4, $50 \%$ of the ligand is still free, even though there is a significant amout of the species $\left[\mathrm{Ca}_{4}\left(\mathrm{H}_{2} \mathrm{~L}\right)\right]$. The presence of excess Ins $(1,3,4,5,6) P_{5}$ in the system changes the speciation diagram slightly, giving rise to lower concentrations of free $\mathrm{Ca}^{2+}$ at acidic $\mathrm{pH}$ values (plot not shown). The strengths of the interactions with $\mathrm{Ca}^{2+}$ and $\mathrm{Mg}^{2+}$ are similar; accordingly, the species distribution diagrams for these two cations are similar [Fig. 4, plots given for $1 \mathrm{mM}$ Ins $(1,3,4,5,6) P_{5}$ and $\left.1 \mathrm{mM} \mathrm{M}^{2+}\right]$. Although, over the range of divalent cations studied, the interaction with $\operatorname{Ins}(1,3,4,5,6) P_{5}$ is fairly independent of the particular cation (Table 2), slight differences are observed. In particular, the transition metal ions display higher stability constants than the alkaline earth ones, as reflected in the speciation diagrams given in Figs. 4, S2 and S3 for $1 \mathrm{mM}$ Ins $(1,3,4,5,6) P_{5}$ and $1 \mathrm{mM} \mathrm{M}^{2+}$. For example, the amount of $\mathrm{M}^{2+}$ left free at $\mathrm{pH} 7.4$ is significant for the alkaline earth metal ions (Fig. 4), but is negligible for the transition metal ones (Figs. S2, S3 for $\mathrm{Cu}^{2+}$ and $\mathrm{Fe}^{2+}$, respectively).

In comparison with the divalent cations, $\mathrm{Fe}^{3+}$ forms much more stable complexes with $\operatorname{Ins}(1,3,4,5,6) P_{5}$. The higher values of the stability constants (Table 2) are reflected in the species distribution diagram (Fig. 5), in which the highly deprotonated species $[\mathrm{Fe}(\mathrm{HL})]^{6-}$ predominates at $\mathrm{pH}$ 7.4. The higher charge of the central atom in comparison with the divalent cations gives rise to stronger interactions and consequently to a higher extent of ligand deprotonation.
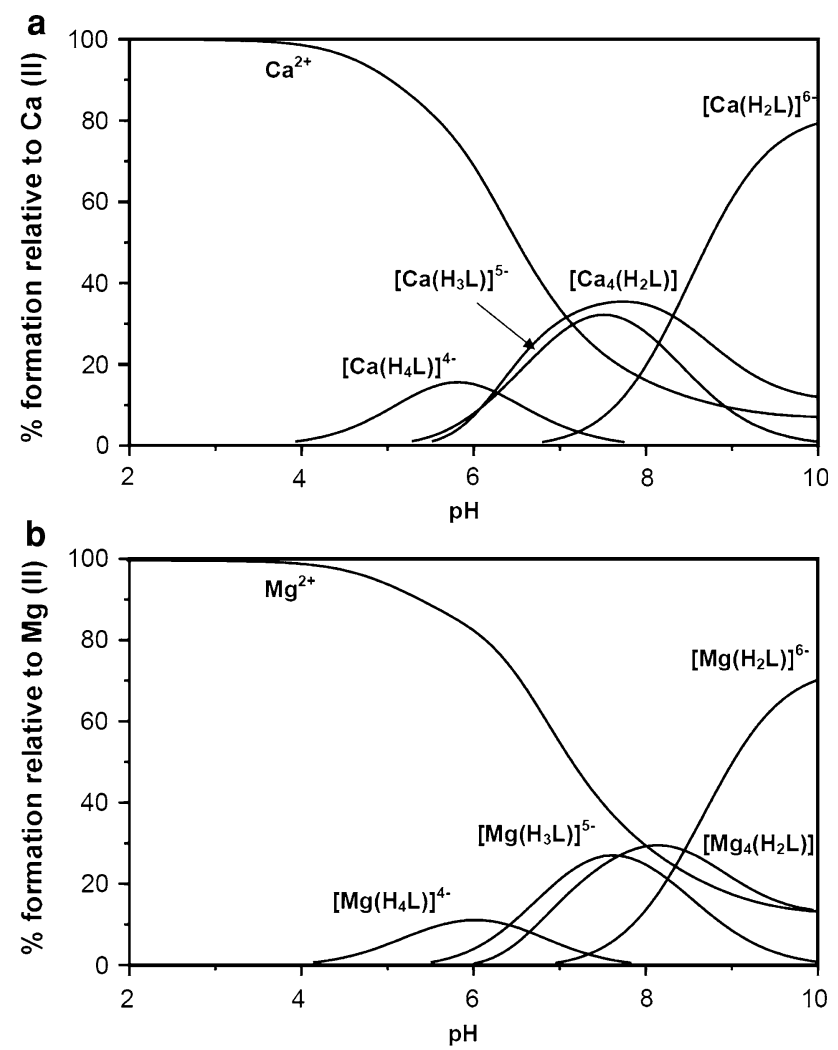

Fig. 4 Species distribution diagram for $1 \mathrm{mM} \operatorname{Ins}(1,3,4,5,6) P_{5}$ in the presence of alkaline earth metal ions, in $0.15 \mathrm{M} \mathrm{Me}_{4} \mathrm{NCl}$, at $37.0{ }^{\circ} \mathrm{C}$ : a $1 \mathrm{mM} \mathrm{Ca}^{2+} ;$ b $1 \mathrm{mM} \mathrm{Mg}^{2+}$

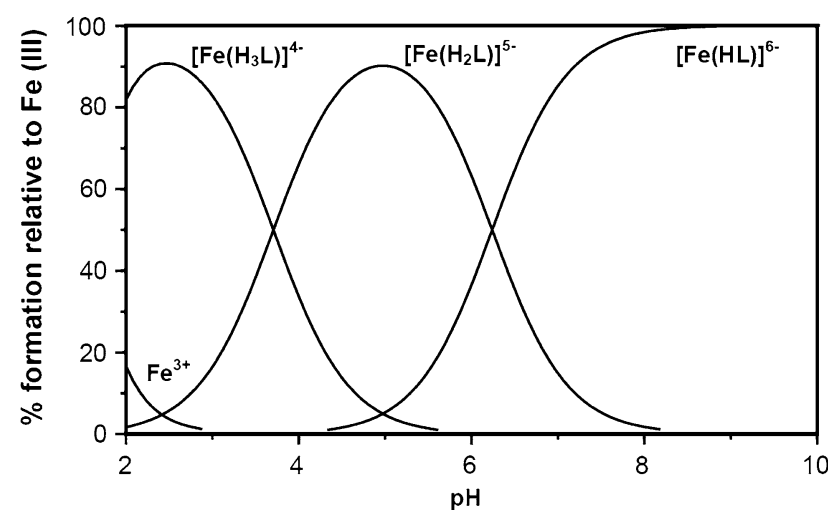

Fig. 5 Species distribution diagram for $1 \mathrm{mM} \operatorname{Ins}(1,3,4,5,6) P_{5}$ in the presence of $1 \mathrm{mM} \mathrm{Fe}^{3+}$, in $0.15 \mathrm{M} \mathrm{Me}_{4} \mathrm{NCl}$, at $37.0^{\circ} \mathrm{C}$

Comparative coordination ability of $\operatorname{Ins} P_{6}$, $\operatorname{Ins}(1,3,4,5,6) P_{5}$ and $\operatorname{Ins}(1,2,3) P_{3}$

During the last few years, we have reported quantitative data on the interaction of $\operatorname{Ins} P_{6}, \operatorname{Ins}(1,2,3) P_{3}$ and now Ins $(1,3,4,5,6) P_{5}$ with metal ions [13-16]. It is therefore possible to compare the metal complexation behaviours of these three InsPs. A direct comparison of the stability constants is not straightforward because of the different 
complex species formed and the different degrees of protonation that the ligands can exhibit. Nonetheless, the overall strengths of interaction can be compared in terms of the quotient between bound ligand and unbound ligand. This quotient represents the fraction of all complex species containing Ins $P$ and metal relative to all forms of the free ligand. Taking $\mathrm{K}^{+}$for example, the complexes formed with $\operatorname{Ins} P_{x}$ are $\left[\mathrm{K}_{3}\left(\mathrm{H}_{4} \mathrm{~L}\right)\right]^{5-},\left[\mathrm{K}_{4}\left(\mathrm{H}_{3} \mathrm{~L}\right)\right]^{5-},\left[\mathrm{K}_{5}\left(\mathrm{H}_{2} \mathrm{~L}\right)\right]^{5-}$ and $\left[\mathrm{K}_{6} \mathrm{~L}\right]^{6-}$ for Ins $P_{6},\left[\mathrm{~K}_{4} \mathrm{~L}\right]^{6-},\left[\mathrm{K}_{3}(\mathrm{HL})\right]^{6-}$ and $\left[\mathrm{K}_{2}\left(\mathrm{H}_{2} \mathrm{~L}\right)\right]^{6-}$ for $\operatorname{Ins}(1,3,4,5,6) P_{5}$ and $[\mathrm{KL}]^{5-},[\mathrm{K}(\mathrm{HL})]^{4-},\left[\mathrm{K}\left(\mathrm{H}_{2} \mathrm{~L}\right)\right]^{3-}$ and $\left[\mathrm{K}_{2}\left(\mathrm{H}_{4} \mathrm{~L}\right)\right]$ for $\operatorname{Ins}(1,2,3) P_{3}$. So the quotients, $Q$, are calculated as follows: be expected to shift the relative strengths of interaction in favour of both $\operatorname{Ins} P_{6}$ and $\operatorname{Ins}(1,3,4,5,6) P_{5}$ with respect to Ins $(1,2,3) P_{3}$; however, the occurrence of precipitation in this range (see below) makes it difficult to draw meaningful plots analogous to that in Fig. 6.

The interaction with $\mathrm{Fe}^{3+}$ is very strong for the three Ins $P$ s. The $\log Q$ values are high and increase in very similar ways (from about 3 to about 7) between $\mathrm{pH} 4$ and 7 , while above $\mathrm{pH} 7, \operatorname{Ins}(1,3,4,5,6) P_{5}$ becomes a more effective $\mathrm{Fe}^{3+}$ chelator than the other two Ins $P$ s, especially in comparison with $\operatorname{Ins} P_{6}$. These results are unexpected, because, unlike $\operatorname{Ins}(1,2,3) P_{3}$ and $\operatorname{Ins} P_{6}, \operatorname{Ins}(1,3,4,5,6) P_{5}$

$$
\begin{aligned}
& Q_{\text {Ins } P_{6}}=\frac{\left(\left[\mathrm{K}_{3}\left(\mathrm{H}_{4} \mathrm{~L}\right)\right]^{5-}+\left[\mathrm{K}_{4}\left(\mathrm{H}_{3} \mathrm{~L}\right)\right]^{5-}+\left[\mathrm{K}_{5}\left(\mathrm{H}_{2} \mathrm{~L}\right)\right]^{5-}+\left[\mathrm{K}_{6} \mathrm{~L}\right]^{6-}\right)}{\left(\mathrm{L}^{12-}+\mathrm{HL}^{11-}+\mathrm{H}_{2} \mathrm{~L}^{10-}+\mathrm{H}_{3} \mathrm{~L}^{9-}+\mathrm{H}_{4} \mathrm{~L}^{8-}+\mathrm{H}_{5} \mathrm{~L}^{7-}+\mathrm{H}_{6} \mathrm{~L}^{6-}+\mathrm{H}_{7} \mathrm{~L}^{5-}+\mathrm{H}_{8} \mathrm{~L}^{4-}+\mathrm{H}_{9} \mathrm{~L}^{3-}\right)} \\
& Q_{\operatorname{Ins}(1,3,4,5,6) P_{5}}=\frac{\left(\left[\mathrm{K}_{4} \mathrm{~L}\right]^{6-}+\left[\mathrm{K}_{3}(\mathrm{HL})\right]^{6-}+\left[\mathrm{K}_{2}\left(\mathrm{H}_{2} \mathrm{~L}\right)\right]^{6-}\right)}{\left(\mathrm{L}^{10-}+\mathrm{HL}^{9-}+\mathrm{H}_{2} \mathrm{~L}^{8-}+\mathrm{H}_{3} \mathrm{~L}^{7-}+\mathrm{H}_{4} \mathrm{~L}^{6-}+\mathrm{H}_{5} \mathrm{~L}^{5-}+\mathrm{H}_{6} \mathrm{~L}^{4-}+\mathrm{H}_{7} \mathrm{~L}^{3-}\right)}
\end{aligned}
$$

$$
\begin{aligned}
& Q_{\operatorname{Ins}(1,2,3) P_{3}} \\
& =\frac{\left([\mathrm{KL}]^{5-}+[\mathrm{K}(\mathrm{HL})]^{4-}+\left[\mathrm{K}\left(\mathrm{H}_{2} \mathrm{~L}\right)\right]^{3-}+\left[\mathrm{K}_{2}\left(\mathrm{H}_{4} \mathrm{~L}\right)\right]\right)}{\left(\mathrm{L}^{6-}+\mathrm{HL}^{5-}+\mathrm{H}_{2} \mathrm{~L}^{4-}+\mathrm{H}_{3} \mathrm{~L}^{3-}+\mathrm{H}_{4} \mathrm{~L}^{2-}\right)}
\end{aligned}
$$

The $\log Q$ values for three ions, $\mathrm{K}^{+}, \mathrm{Mg}^{2+}$ and $\mathrm{Fe}^{3+}$, are plotted in Fig. 6 as a function of pH, for $1 \mathrm{mM}$ cation and ligand. Their values increase sharply with cation charge (from $\mathrm{K}^{+}$to $\mathrm{Fe}^{3+}$ ), as expected of predominantly electrostatic interactions.

With respect to $\mathrm{K}^{+}$, Ins $(1,2,3) P_{3}$ exhibits the strongest interaction at any $\mathrm{pH}$ value under the conditions studied (Fig. 6). This is possible because under 1:1 metal-ligand conditions, polymetallic species (which are formed by $\operatorname{Ins}(1,3,4,5,6) P_{5}$ and $\operatorname{Ins} P_{6}$ but not by $\operatorname{Ins}(1,2,3) P_{3}$ except for $\left[\mathrm{K}_{2}\left(\mathrm{H}_{4} \mathrm{~L}\right)\right]$ under acidic conditions) are quantitatively irrelevant. Under metal-excess conditions (100:1), which favour coordinative interactions in complexes between $\operatorname{Ins}(1,3,4,5,6) P_{5}$ or $\operatorname{Ins} P_{6}$ and two to six $\mathrm{K}^{+}$ions, the scenario changes, with $\operatorname{Ins} P_{6}$ displaying the strongest interaction above $\mathrm{pH} 8$ (Fig. S4).

The strongest interaction towards $\mathrm{Mg}^{2+}$ is clearly established by $\operatorname{Ins} P_{6}$, as expected from the fact that it is the most highly charged of the three compounds at any $\mathrm{pH}$ value. Ins $P_{6}$ forms with $\mathrm{Mg}^{2+}$, in addition to $1: 1 \mathrm{com}$ plexes, the neutral species $\left[\mathrm{Mg}_{5}\left(\mathrm{H}_{2} \mathrm{~L}\right)\right]$, analogous to the neutral $\left[\mathrm{Mg}_{4}\left(\mathrm{H}_{2} \mathrm{~L}\right)\right]$ complex now described for Ins $(1,3,4,5,6) P_{5}$ (Table 2). Under conditions of metal excess, the formation of such polymetallic complexes can

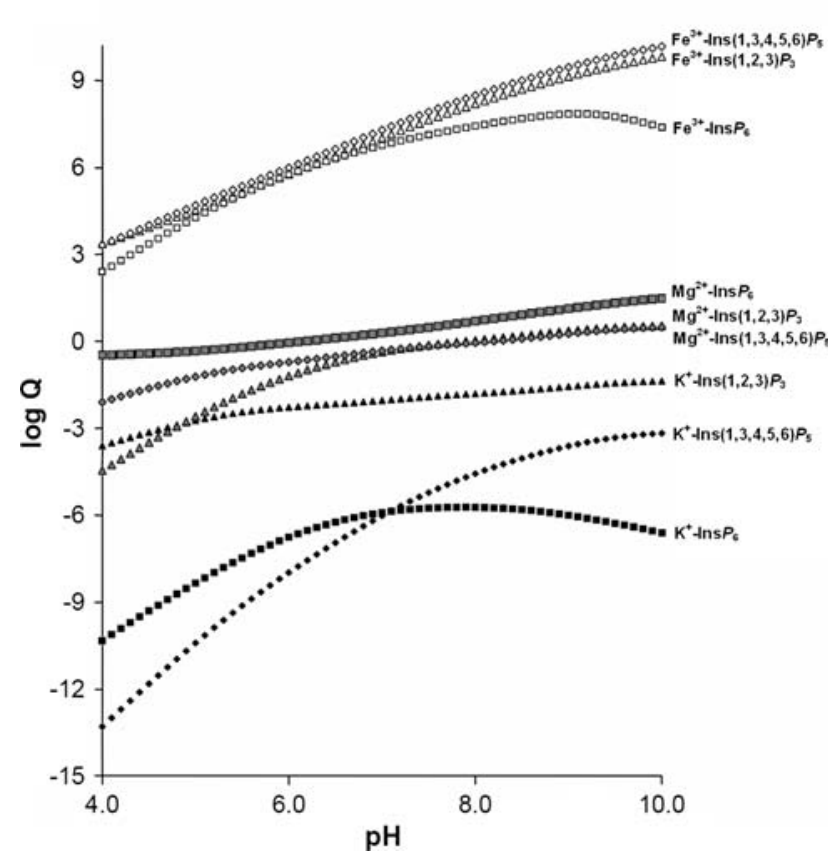

Fig. 6 Comparative behaviour of inositol 1,2,3-trisphosphate $\left[\operatorname{Ins}(1,2,3) P_{3}\right], \operatorname{Ins}(1,3,4,5,6) P_{5}$ and inositol hexakisphosphate $\left(\operatorname{Ins} P_{6}\right)$. The logarithms of the quotients between bound ligand and unbound ligand are plotted versus $\mathrm{pH}$. Other conditions were $0.15 \mathrm{M} \mathrm{Me}{ }_{4} \mathrm{NCl}$, $37.0{ }^{\circ} \mathrm{C}, 1 \mathrm{mM} \operatorname{Ins}(1,2,3) P_{3}, 1 \mathrm{mM} \operatorname{Ins}(1,3,4,5,6) P_{5}, 1 \mathrm{mM} \operatorname{Ins} P_{6}$, $1 \mathrm{mM} \mathrm{K}^{+}, 1 \mathrm{mM} \mathrm{Mg}^{2+}$ and $1 \mathrm{mM} \mathrm{Fe}^{3+}$. The equilibrium constants used were taken from this and previous reports [13-16] 
lacks the 1,2,3-trisphosphate motif usually believed to be necessary and sufficient for high-affinity complexation of this cation by Ins $P$ s. In derivatives of myo-inositol, the substituent at C-2 is the only axial one (see Fig. 1), and therefore the 1,2,3-trisphosphate motif is unique in having three phosphates in a cis relationship to one another. This motif is thought to flip to the normally unfavourable axialequatorial-axial disposition upon the complexation of $\mathrm{Fe}^{3+}$ [23]. In contrast, Ins $(1,3,4,5,6) P_{5}$ has all its phosphates in the equatorial form (and it is highly unlikely to adopt a thermodynamically unfavourable all-axial conformation). The evidence for the importance of the 1,2,3-trisphosphate motif comes from assays in which the Ins $P$ s prevent the iron-catalysed generation of hydroxyl radical through the Fenton reaction. All Ins $P$ s tested so far that contain the 1,2,3-trisphosphate motif, including $\operatorname{Ins} P_{6}$ and $\operatorname{Ins}(1,2,3) P_{3}$, are highly effective at preventing hydroxyl radical formation, while those lacking this motif, including Ins $(1,3,4,5,6) P_{5}$ in particular, are clearly less effective [24, 25]. Our results thus indicate that high-affinity complexation of $\mathrm{Fe}^{3+}$ by Ins $P$ s does not require the equatorial-axialequatorial 1,2,3-trisphosphate motif, and is thus a separate property from their capacity to inhibit the iron-catalysed production of hydroxyl radical. Therefore all-equatorial vicinal trisphosphate groups, as present in $\operatorname{Ins}(1,3,4,5,6) P_{5}$, appear to support $\mathrm{Fe}^{3+}$ complexation of at least as high affinity as the 1,2,3-trisphosphate motif, but with the difference that iron is not prevented effectively from participating in the Fenton reaction.

Biological predictions for Ins $(1,3,4,5,6) P_{5}$ under cytosolic/nuclear conditions of mammalian cells

Although other localizations have not been ruled out, most Ins $(1,3,4,5,6) P_{5}$ in mammalian cells is thought to be present in the cytosolic and/or nuclear compartment(s) [26]. In yeast cells at least, the metabolite appears to be able to diffuse freely between cytosol and nucleus; this implies that at least a significant portion of the compound is protein-free and/or forming only low molecular mass complexes [27]. Therefore, our data for the complexation behaviour of Ins $(1,3,4,5,6) P_{5}$ in solution, together with the known concentrations of major cations in cytosol/nucleus, can be used for predicting the probable major form(s) of the compound in living cells. Solubility constants are not needed for these calculations because the data presented below indicate that $\operatorname{Ins}(1,3,4,5,6) P_{5}$ cannot be expected to precipitate at its reported concentration range in mammalian cells of approximately 10-100 $\mu \mathrm{M}$ [28-30] (a different situation arises with certain non-mammalian erythrocytes, as further discussed below). For the calculations, we chose $50 \mu \mathrm{M}$ Ins $(1,3,4,5,6) P_{5}, 150 \mathrm{mM} \mathrm{K}^{+}$and $\mathrm{pH} 7.4$ [31]. We further chose concentrations of free $\mathrm{Mg}^{2+}$ that correspond approximately to the extremes and midpoint of the current estimated range $(0.25-1 \mathrm{mM})$ [32]; note that setting the concentration of free $\mathrm{Mg}^{2+}$ to a particular approximate value in this system means setting the total concentration of $\mathrm{Mg}^{2+}$ at values that are slightly higher, so as to allow for the amount of $\mathrm{Mg}^{2+}$ that is complexed by $\operatorname{Ins}(1,3,4,5,6) P_{5}$. The results (Table 3$)$ predict that $\operatorname{Ins}(1,3,4,5,6) P_{5}$ is partly associated with $\mathrm{Mg}^{2+}$ but partly unbound to cations. A small proportion is also predicted to be associated with $\mathrm{K}^{+}$. The $\mathrm{Mg}^{2+}$-associated $\operatorname{Ins}(1,3,4,5,6) P_{5}$ is predicted to consist mostly of the neutral complex $\left[\mathrm{Mg}_{4}\left(\mathrm{H}_{2} \mathrm{~L}\right)\right]$ but also of the anionic $1: 1$ species $\left[\mathrm{Mg}\left(\mathrm{H}_{3} \mathrm{~L}\right)\right]^{5-}$. The cation-free Ins $(1,3,4,5,6) P_{5}$ is predicted to exist predominantly as the highly charged species $\left[\mathrm{H}_{4} \mathrm{~L}\right]^{6-}$ and $\left[\mathrm{H}_{3} \mathrm{~L}\right]^{7-}$. This contrasts with the behaviour of $\operatorname{Ins} P_{6}$, which is predicted to associate fully with $\mathrm{Mg}^{2+}$, as $\left[\mathrm{Mg}_{5}\left(\mathrm{H}_{2} \mathrm{~L}\right)\right]$, under the same conditions [14].

We had previously shown that $\operatorname{Ins} P_{6}$, because of its association with $\mathrm{Mg}^{2+}$, cannot bind $\mathrm{Fe}^{3+}$ under simulated cytosolic/nuclear conditions [14]. In contrast, Ins(1,2,3) $P_{3}$ associates much more weakly with $\mathrm{Mg}^{2+}$, and is able to bind fully $\mathrm{Fe}^{3+}$ present in equimolar amounts [16]. The weak association with $\mathrm{Mg}^{2+}$ and the high cellular concentration of Ins $(1,3,4,5,6) P_{5}$ mean that if a small concentration of $\mathrm{Fe}^{3+}$ (representing the "chelatable iron pool", the size of which is unknown [33]) is included in the simulations, this iron associates completely with Ins $(1,3,4,5,6) P_{5}$ (Table 3$)$.

Table 3 Predictions for Ins $(1,3,4,5,6) P_{5}$ under simulated cytosolic/nuclear conditions, in the absence and presence of $\mathrm{Fe}^{3+}$

\begin{tabular}{|c|c|c|c|c|c|c|c|c|c|}
\hline$\left[\mathrm{Mg}^{2+}\right]_{\text {total }}(\mu \mathrm{M})$ & 350 & 600 & 1,150 & 350 & 600 & 1,150 & 350 & 600 & 1,150 \\
\hline$\left[\mathrm{Fe}^{3+}\right](\mu \mathrm{M})$ & 0 & 0 & 0 & 1 & 1 & 1 & 10 & 10 & 10 \\
\hline$\left[\mathrm{Mg}^{2+}\right]_{\text {free }}(\mu \mathrm{M})$ & 332 & 557 & 1,026 & 333 & 558 & 1028 & 336 & 565 & 1,048 \\
\hline $\operatorname{Ins}(1,3,4,5,6) P_{5}$ associated with $\mathrm{Mg}^{2+}(\%)$ & 29 & 47 & 80 & 29 & 46 & 78 & 24 & 38 & 65 \\
\hline Ins $(1,3,4,5,6) P_{5}$ associated with $\mathrm{K}^{+}(\%)$ & 6 & 5 & 2 & 6 & 5 & 2 & 5 & 4 & 1 \\
\hline Unbound $\operatorname{Ins}(1,3,4,5,6) P_{5}(\%)$ & 65 & 48 & 18 & 63 & 47 & 18 & 51 & 38 & 14 \\
\hline Ins $(1,3,4,5,6) P_{5}$ associated with $\mathrm{Fe}^{3+}(\%)$ & 0 & 0 & 0 & 2 & 2 & 2 & 20 & 20 & 20 \\
\hline $\mathrm{Fe}^{3+}$ associated with $\operatorname{Ins}(1,3,4,5,6) P_{5}(\%)$ & 0 & 0 & 0 & 100 & 100 & 100 & 100 & 100 & 100 \\
\hline
\end{tabular}

The conditions are $50 \mu \mathrm{M} \operatorname{Ins}(1,3,4,5,6) P_{5}, 0.15 \mathrm{M} \mathrm{K}^{+}$and $\mathrm{pH} 7.4$ throughout. Values for $\left[\mathrm{Mg}^{2+}\right]_{\text {total }}$ were chosen so that $\left[\mathrm{Mg}^{2+}\right]_{\text {free }}$ falls in different points of the $0.25-1-\mathrm{mM}$ range believed to exist in the cytosol and nucleus of mammalian cells 
However, we feel unsure about the biological significance of this result since cellular iron ligands are expected to prevent the participation of iron in the Fenton reaction, a property that $\operatorname{Ins}(1,3,4,5,6) P_{5}$ lacks.

Ins $(1,3,4,5,6) P_{5}$ solids with calcium and magnesium: synthesis and IR spectra

The interaction of $\mathrm{M}^{2+}$ ions with $\operatorname{Ins}(1,3,4,5,6) P_{5}$ under metal excess gives rise to the formation of fairly insoluble compounds. We prepared and analysed the solids with $\mathrm{Ca}^{2+}$ and $\mathrm{Mg}^{2+}$. The elemental and thermogravimetric analyses agreed with the general formula $\left[\mathrm{M}_{4}\left(\mathrm{H}_{2} \mathrm{~L}\right)\right] \cdot x \mathrm{H}_{2} \mathrm{O}$ $[x=23(\mathrm{Mg}), 16(\mathrm{Ca})]$. Therefore, the calcium and magnesium solids have the same metal-to-ligand stoichiometry as the neutral tetrametallic complexes formed with these cations in solution. The solids, as expected, also include a number of water molecules, which are lost during thermogravimetric analysis across a wide temperature range, namely between 50 and $210{ }^{\circ} \mathrm{C}$.

Table 4 shows the most intense and characteristic bands present in the IR spectra of $\left(\mathrm{NH}_{4}\right)_{6} \mathrm{H}_{4} \mathrm{~L},\left[\mathrm{Mg}_{4}\left(\mathrm{H}_{2} \mathrm{~L}\right)\right]$. $23 \mathrm{H}_{2} \mathrm{O}$ and $\left[\mathrm{Ca}_{4}\left(\mathrm{H}_{2} \mathrm{~L}\right)\right] \cdot 16 \mathrm{H}_{2} \mathrm{O}$. The ammonium salt has five phosphate groups and four acidic protons. Owing to the extensive proton sharing reported for $\operatorname{Ins} P_{6}$ [34], we can assume that all the phosphate groups are linked to at least one hydrogen. Accordingly, the IR spectrum obtained is similar to that of $\mathrm{H}_{2} \mathrm{PO}_{4}^{-}$, and can be interpreted using this species as a model [35]. The $\mathrm{O}-\mathrm{H}, \mathrm{N}-\mathrm{H}$ and $\mathrm{C}-\mathrm{H}$ bond stretching peaks appear as a wide and intense band in the interval 2,500-3,600 $\mathrm{cm}^{-1}$ [35-37]. A sharp and intense peak at $1,400 \mathrm{~cm}^{-1}$ can be assigned to the $\mathrm{H}-\mathrm{N}-\mathrm{H}$ bending mode of the ammonium cation [37]. Finally, the vibrations involving the phosphate groups appear in the interval 500 $1,200 \mathrm{~cm}^{-1}$. The O-P-O bending mode is found at about $514 \mathrm{~cm}^{-1}$, while the symmetric and antisymmetric stretching modes are observed at about 850 and $980 \mathrm{~cm}^{-1}$, respectively [35]. Probably the stretching of the $\mathrm{C}-\mathrm{O}$ bond also falls in this region [37]. Three more bands of great intensity are observed at $1,058,1,128$ and $1,183 \mathrm{~cm}^{-1}$, and can be assigned to the symmetric and antisymmetric stretching of the $\mathrm{PO}_{2}{ }^{-}$group [35]. It is possible to analyse the contributions of the phosphate groups to some of the bands by using the IR study on dodecasodium phytate reported by He et al. [38]. Assuming that there are mainly two groups of phosphates in the ligand, those bound to C-1 and $\mathrm{C}-3$ would have an important contribution to the bands at 812 and $932 \mathrm{~cm}^{-1}$, while the bands at 850 and $981 \mathrm{~cm}^{-1}$ could be associated with the vibration of those phosphate groups on C-4, C-5 and C-6. It is worth mentioning that, as expected, the bands mainly related with the vibrations of C-2 phosphate group are not present in the experimental spectrum [38].

The IR spectra of the magnesium and calcium solids are very similar, indicative of isostructural compounds, differing only in the number of water molecules. A similar behaviour was observed for the magnesium and calcium solids of Ins $P_{6}$ [13]. The $\delta(\mathrm{H}-\mathrm{N}-\mathrm{H})$ peak is absent from the spectra of the magnesium and calcium solids of Ins $(1,3,4,5,6) P_{5}$, attesting to a complete $\mathrm{NH}_{4}{ }^{+}-\mathrm{Mg}^{2+} / \mathrm{Ca}^{2+}$ exchange during the syntheses. Complexation with the $\mathrm{M}$ (II) ions introduces several changes in the IR spectra (in comparison with the spectrum of the ammonium salt), the normal modes associated with phosphate groups being the most affected. The stretching signals of the $\mathrm{PO}_{2}^{-}$group (five bands in the ligand) appear now as two intense peaks at about 990 and $1,120 \mathrm{~cm}^{-1}$, which are probably associated with $v_{\mathrm{s}}\left(\mathrm{PO}_{2}^{-}\right)$and $v_{\mathrm{as}}\left(\mathrm{PO}_{2}^{-}\right)$, respectively. This fact (only two sharp and broad bands, with a small difference between them) was already reported for $\mathrm{Ca}^{2+}$ and $\mathrm{Mg}^{2+}$ solids of Ins $P_{6}[13,38]$. Besides, the frequency for the $\mathrm{O}_{-}$ $\mathrm{P}-\mathrm{O}$ bending mode changes upon coordination to higher wavenumber values. These two facts suggest that the metal cations are bound to the phosphate groups, possibly by means of a direct and bidentate $\mathrm{M}-\mathrm{O}-\mathrm{P}$ coordination [13].

Solubility of $\operatorname{Ins}(1,3,4,5,6) P_{5}$ solids with calcium and magnesium

The $\mathrm{Mg}^{2+}$ and $\mathrm{Ca}^{2+}$ solids of $\operatorname{Ins}(1,3,4,5,6) P_{5}$ are only sparingly soluble in water. Therefore, a complete, biologically relevant description of the chemical systems containing $\operatorname{Ins}(1,3,4,5,6) P_{5}$ and these two cations requires the evaluation of the solubility product constants, $K_{\mathrm{s} 0}=\left[\mathrm{M}^{2+}\right]^{4}\left[\mathrm{H}_{2} \mathrm{~L}^{8-}\right]$. Determination of the $K_{\mathrm{s} 0}$ values obviously requires quantification of the concentrations of

Table 4 IR bands and assignments for Ins $(1,3,4,5,6) P_{5}$ and its solid complexes with magnesium and calcium

\begin{tabular}{|c|c|c|c|c|c|c|c|c|}
\hline Compound & $\begin{array}{l}v(\mathrm{O}-\mathrm{H}) \\
v(\mathrm{C}-\mathrm{H})\end{array}$ & $\delta(\mathrm{H}-\mathrm{N}-\mathrm{H})$ & $v_{\mathrm{as}}\left(\mathrm{PO}_{2}^{-}\right)$ & $v_{\mathrm{s}}\left(\mathrm{PO}_{2}{ }^{-}\right)$ & $\begin{array}{l}v_{\text {as }}(\mathrm{O}-\mathrm{P}-\mathrm{O}) \\
v(\mathrm{PO}-\mathrm{C})\end{array}$ & $v(\mathrm{P}-\mathrm{OH})$ & $v_{\mathrm{s}}(\mathrm{O}-\mathrm{P}-\mathrm{O})$ & $\delta(\mathrm{O}-\mathrm{P}-\mathrm{O})$ \\
\hline \multirow[t]{2}{*}{$\left(\mathrm{NH}_{4}\right)_{6}\left(\mathrm{H}_{4} \mathrm{~L}\right)$} & $2,500-3,600$ & 1,401 & 1,183 & 1,058 & 981 & & 850 & 514 \\
\hline & & & 1,128 & & 932 & & 812 & \\
\hline$\left[\mathrm{Mg}_{4}\left(\mathrm{H}_{2} \mathrm{~L}\right)\right] \cdot 23 \mathrm{H}_{2} \mathrm{O}$ & $2,600-3,600$ & & 1,119 & 996 & & 847 & & 551 \\
\hline$\left[\mathrm{Ca}_{4}\left(\mathrm{H}_{2} \mathrm{~L}\right)\right] \cdot 16 \mathrm{H}_{2} \mathrm{O}$ & $2,600-3,600$ & & 1,123 & 990 & & 844 & & 540 \\
\hline
\end{tabular}


$\mathrm{H}_{2} \mathrm{~L}^{8-}$ and of the free metal ions at equilibrium with the solids. These can in turn be calculated from the straightforward analytical data by means of appropriate software programs such as HySS [21], fed with the complete set of equilibrium constants for the protonation and complexation equilibria, as reported previously by us for $\operatorname{Ins} P_{6}$ [13]. We thus obtained values for $K_{\mathrm{s} 0}$,

$$
\begin{aligned}
& {\left[\mathrm{Mg}_{4}\left(\mathrm{H}_{2} \mathrm{~L}\right)\right] \rightarrow 4 \mathrm{Mg}^{2+}+\mathrm{H}_{2} \mathrm{~L}^{8-} \quad \log K_{\mathrm{s} 0}=-18.6(1)} \\
& {\left[\mathrm{Ca}_{4}\left(\mathrm{H}_{2} \mathrm{~L}\right)\right] \rightarrow 4 \mathrm{Ca}^{2+}+\mathrm{H}_{2} \mathrm{~L}^{8-} \quad \log K_{\mathrm{s} 0}=-20.2(4),}
\end{aligned}
$$

which are valid at $I=0.15 \mathrm{M} \mathrm{Me}_{4} \mathrm{NCl}$ and $37.0{ }^{\circ} \mathrm{C}$. The lower $K_{\mathrm{s} 0}$ value for calcium reflects the lower solubility of the $\mathrm{Ca}^{2+}$ solid in comparison with the $\mathrm{Mg}^{2+}$ one.

Figure 7 shows the speciation of $\operatorname{Ins}(1,3,4,5,6) P_{5}$ in the presence of $\mathrm{Ca}^{2+}$ and of $\mathrm{Mg}^{2+}$, under the conditions which applied for Fig. 4 [1 mM Ins $\left.(1,3,4,5,6) P_{5}, 1 \mathrm{mM} \mathrm{M}^{2+}\right]$, but now including the solubility behaviours (and plotting in terms of total ligand instead of metal). It can be seen that while a small amount of the $\mathrm{Ca}^{2+}$ solid is predicted to form at $\mathrm{pH}$ values near neutrality, the more soluble $\mathrm{Mg}^{2+}$ salt does not precipitate under the same conditions. As further discussed below, the prerequisite for significant precipitation to take place in these systems is the dominance in

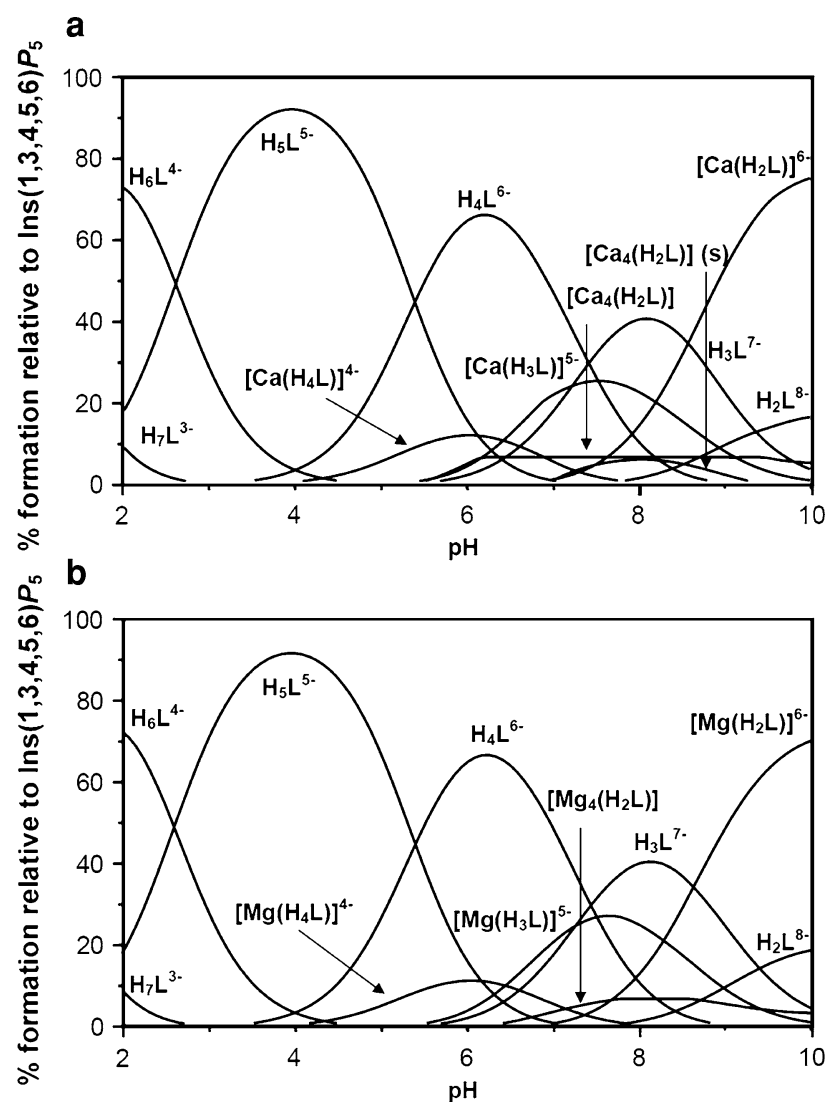

Fig. 7 Species distribution diagram for $1 \mathrm{mM} \operatorname{Ins}(1,3,4,5,6) P_{5}$ interaction in the presence of alkaline earth metal ions, in $0.15 \mathrm{M} \mathrm{Me}_{4} \mathrm{NCl}$, at $37.0{ }^{\circ} \mathrm{C}$, including solubility values: a $1 \mathrm{mM} \mathrm{Ca}^{2+}$, b $1 \mathrm{mM} \mathrm{Mg}^{2+}$ solution of the $\left[\mathrm{M}_{4}\left(\mathrm{H}_{2} \mathrm{~L}\right)\right]$ complexes, and this occurs only under considerable metal excess.

Complete description of the behaviour

of Ins $(1,3,4,5,6) P_{5}$ in the presence of $\mathrm{Ca}^{2+}$ and/or $\mathrm{Mg}^{2+}$

The protonation constants of $\operatorname{Ins}(1,3,4,5,6) P_{5}$, together with the $\mathrm{Ca}^{2+}$ and $\mathrm{Mg}^{2+}$ complexation constants and the $K_{\mathrm{s} 0}$ values, allow a complete description of the speciation of Ins $(1,3,4,5,6) P_{5}$ in the presence of $\mathrm{Ca}^{2+} / \mathrm{Mg}^{2+}$. Broadly, the behaviour is characterized by the predominance of soluble 1:1 species under $\operatorname{Ins}(1,3,4,5,6) P_{5}$ excess and the predominance of the tetrametallic species $\left[\mathrm{M}_{4}\left(\mathrm{H}_{2} \mathrm{~L}\right)\right]$ under metal excess. The $\left[\mathrm{M}_{4}\left(\mathrm{H}_{2} \mathrm{~L}\right)\right]$ complexes exist in solution up to fixed concentration limits, and any amount of them that forms in excess of those limits undergoes precipitation. Such concentration limits are given by the product of the value of each stability constant $\left(4 \mathrm{M}^{2+}+\mathrm{H}_{2} \mathrm{~L}^{8-}\right.$ $\left.\leftrightarrow\left[\mathrm{M}_{4}\left(\mathrm{H}_{2} \mathrm{~L}\right)\right]\right)$ and the corresponding value of $K_{\mathrm{s} 0}[13]$, and they thus are $135 \mu \mathrm{M}$ for $\left[\mathrm{Mg}_{4}\left(\mathrm{H}_{2} \mathrm{~L}\right)\right]$ and $56 \mu \mathrm{M}$ for $\left[\mathrm{Ca}_{4}\left(\mathrm{H}_{2} \mathrm{~L}\right)\right]$. Therefore, under conditions of predominance of the $\left[\mathrm{M}_{4}\left(\mathrm{H}_{2} \mathrm{~L}\right)\right]$ complexes [large excess of $\mathrm{M}^{2+}$ with respect to $\operatorname{Ins}(1,3,4,5,6) P_{5}$, neutral or alkaline $\left.\mathrm{pH}\right]$, these fixed values correspond in practice to the total solubility of Ins $(1,3,4,5,6) P_{5}$.

The behaviour of $\operatorname{Ins}(1,3,4,5,6) P_{5}$ in the presence of $\mathrm{Mg}^{2+}$ or $\mathrm{Ca}^{2+}$ at $\mathrm{pH} 7.5$ is plotted in Fig. 8. For a given cation concentration, increasing the concentration of the ligand causes the abundance of the 1:1 complexes to increase monotonously (Fig. 8a, d). In contrast, the 4:1 species increase and then decrease in abundance, as excess Ins $(1,3,4,5,6) P_{5}$ draws the equilibrium towards the $1: 1$ complexes. The 4:1 complexes accumulate initially as soluble species, but once their solubility limits have been reached (see the "plateaus" in Fig. 8b, e), their additional accumulation takes place with the formation of solids (Fig. 8c, f). On the other hand, if the $\operatorname{Ins}(1,3,4,5,6) P_{5}$ concentration is held constant and the metal concentration is increased, there is an initial rise in the abundance of $1: 1$ complexes (Fig. 8a, d), followed by a later increase in the abundance of $4: 1$ complexes, and finally a decrease in the abundance of $1: 1$ complexes. The abundance of the $4: 1$ species in soluble form increases and [as long as the total Ins $(1,3,4,5,6) P_{5}$ concentration exceeds $135 \mu \mathrm{M}$ for $\mathrm{Mg}^{2+}$ and $56 \mu \mathrm{M}$ for $\mathrm{Ca}^{2+}$ ] they later precipitate (Fig. 8b, c, e, f; see insets in Fig. 8c, f).

The differences between the plots for $\mathrm{Mg}^{2+}$ and $\mathrm{Ca}^{2+}$ are slight, except for the fact that the lower solubility of $\left[\mathrm{Ca}_{4}\left(\mathrm{H}_{2} \mathrm{~L}\right)\right]$ with respect to $\left[\mathrm{Mg}_{4}\left(\mathrm{H}_{2} \mathrm{~L}\right)\right]$ causes the solid to be present across a wider range of conditions in the case of $\mathrm{Ca}^{2+}$. When both $\mathrm{Ca}^{2+}$ and $\mathrm{Mg}^{2+}$ are present, the system behaves in a way similar to what has been described, as long as equal total divalent cation concentrations are 

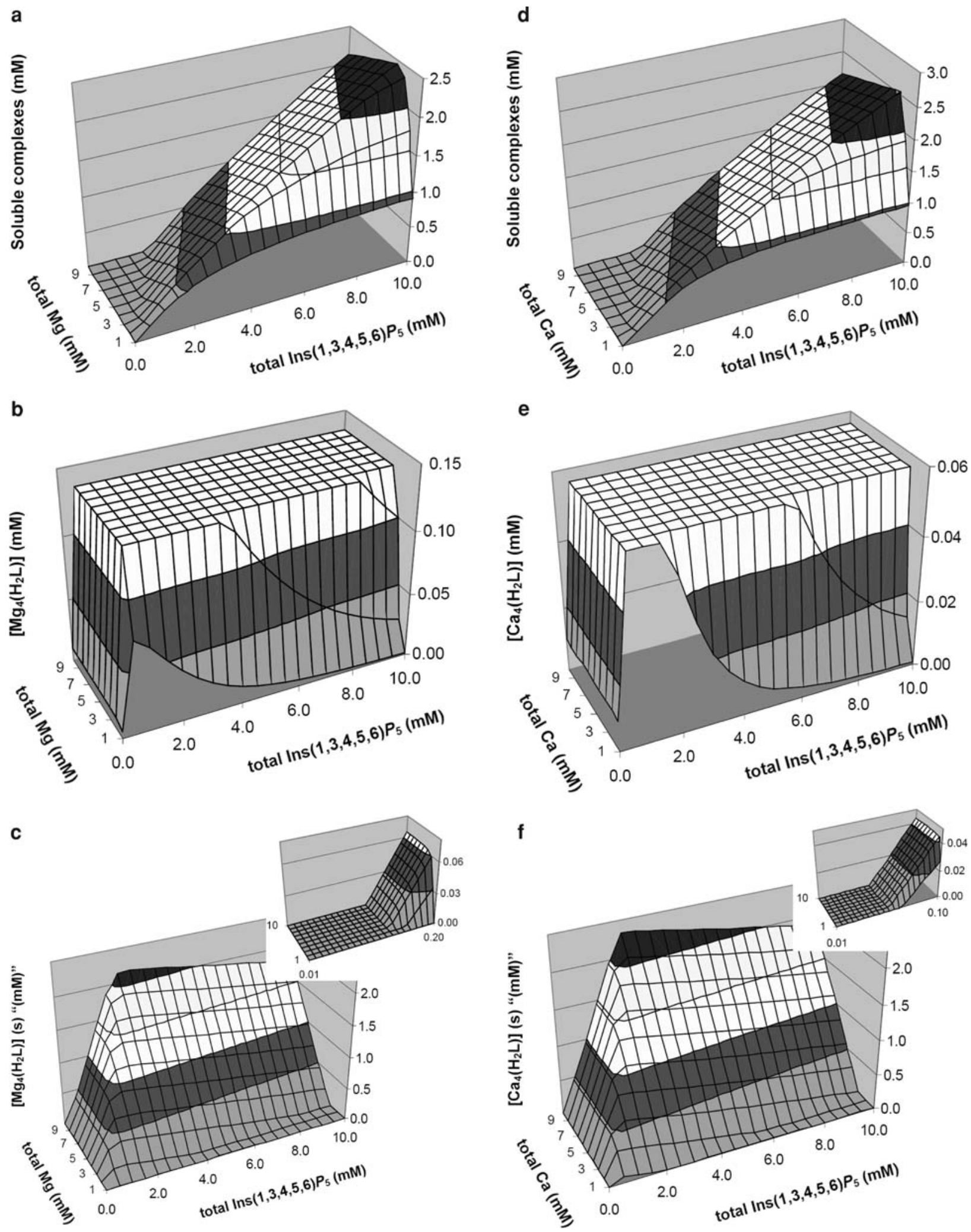

Fig. 8 Behaviour of $\operatorname{Ins}(1,3,4,5,6) P_{5}$ in the presence of magnesium $(\mathbf{a}-\mathbf{c})$ and calcium $(\mathbf{d}-\mathbf{f})$. The graphs show the predicted abundances of the sum of the different soluble 1:1 complexes [a $(\mathrm{Mg}$ 1:1 soluble complexes), d (Ca 1:1 soluble complexes)], of the soluble 4:1 complex [b (Mg 4:1 soluble complex), e (Ca 4:1 soluble complex)],

and of the solid tetrametallic complex [c (Mg solid), $\mathbf{f}$ (Ca solid)], all plotted against total concentrations of $\operatorname{Ins}(1,3,4,5,6) P_{5}(0.01-10 \mathrm{mM})$ and $\mathrm{M}(\mathrm{II})(1-10 \mathrm{mM})$. In $\mathbf{c}$ and $\mathbf{f}$, the insets show "zoom-ins" of the low total Ins $(1,3,4,5,6) P_{5}$ range, in which formation of the solids first appears. Predictions are drawn for $\mathrm{pH} 7.5$, and $37.0^{\circ} \mathrm{C}$ 
considered. Under conditions of total cation excess over Ins $(1,3,4,5,6) P_{5}$, precipitation of the more insoluble $\mathrm{Ca}^{2+}$ complex will be favoured over that of the $\mathrm{Mg}^{2+}$ one.

Overall, this behaviour of $\operatorname{Ins}(1,3,4,5,6) P_{5}$ is similar that of $\operatorname{Ins} P_{6}$ that we reported previously [14] except for the facts that in the Ins $P_{6}$ system (1) the stoichiometry of the neutral polymetallic $\operatorname{Ins} P_{6}$ complex is 5:1 and (2) the solubility limit of the $\mathrm{Mg}^{2+}$ complex is $49 \mu \mathrm{M}$ and that of the $\mathrm{Ca}^{2+}$ one is too low to be measured. An additional finer difference between the systems is that the size of the cation excess needed for complete predominance of the neutral polymetallic species over the anionic $1: 1$ complexes is smaller for $\operatorname{Ins} P_{6}$ than for $\operatorname{Ins}(1,3,4,5,6) P_{5}$ : while systems with Ins $P_{6}$ and either $\mathrm{Mg}^{2+}$ or $\mathrm{Ca}^{2+}$ at 5:1 metal-to-ligand ratios display $\left[\mathrm{Mg}_{5}\left(\mathrm{H}_{2} \mathrm{~L}\right)\right]$ as practically the sole species, similar systems for $\operatorname{Ins}(1,3,4,5,6) P_{5}$ (with $4: 1$ metal-toligand ratios) display a mixture of $\left[\mathrm{Mg}_{4}\left(\mathrm{H}_{2} \mathrm{~L}\right)\right]$ and $1: 1$ species.

Biological predictions for $\operatorname{Ins}(1,3,4,5,6) P_{5}$ present at high concentrations in non-mammalian erythrocytes

Avian and turtle erythrocytes contain very high (millimolar) concentrations of $\operatorname{Ins}(1,3,4,5,6) P_{5}$ (reviewed in [11]). Even if the compound has been proposed to interact with (and modulate the oxygen affinity of) haemoglobin, it is unlikely that the whole of the $\operatorname{Ins}(1,3,4,5,6) P_{5}$ present in these cells is bound to haemoglobin. We ran calculations to predict the physicochemical status of non-haemoglobinbound $\operatorname{Ins}(1,3,4,5,6) P_{5}$ in red blood cells, using as conditions $150 \mathrm{mM} \mathrm{K}^{+}$and $\mathrm{pH}$ 7.4. We explored $\operatorname{Ins}(1,3,4,5,6) P_{5}$ concentrations of 1,3 and $7 \mathrm{mM}$ : this spans the concentrations reported for avian and turtle erythrocytes [39, 40], and takes into account the possibility that the pool of haemoglobin-free Ins $(1,3,4,5,6) P_{5}$ is smaller than the total Ins $(1,3,4,5,6) P_{5}$ one. Also, the $7 \mathrm{mM}$ figure in particular covers the extremely high $\operatorname{Ins}(1,3,4,5,6) P_{5}$ concentrations surprisingly found in the erythrocytes of the Amazonian fish pirarucu during its air-breathing phase (reviewed in [1]). For each $\operatorname{Ins}(1,3,4,5,6) P_{5}$ concentration we explored different figures for the total concentration of $\mathrm{Mg}^{2+}$, so as to obtain free $\mathrm{Mg}^{2+}$ in the $0.2-\mathrm{mM}$ range reported for (mammalian) erythrocytes [41]. The calculations predicted the whole of $\operatorname{Ins}(1,3,4,5,6) P_{5}$ to be soluble (as a mixture of non-complexed anion, $\mathrm{K}^{+}$complexes, and $1: 1 \mathrm{Mg}^{2+}$ complexes, plus a small proportion of $\left.\left[\mathrm{Mg}_{4}\left(\mathrm{H}_{2} \mathrm{~L}\right)\right]\right)$. Precipitation was predicted to start only at higher free $\mathrm{Mg}^{2+}$ concentrations, i.e. approximately $0.32 \mathrm{mM}$ free $\mathrm{Mg}^{2+}$ for $7 \mathrm{mM}$ Ins $(1,3,4,5,6) P_{5}$ and approximately $0.41 \mathrm{mM}$ free $\mathrm{Mg}^{2+}$ for $3 \mathrm{mM} \mathrm{Ins}(1,3,4,5,6) P_{5}$. Interestingly, $\operatorname{Ins} P_{6}$ was predicted (on the basis of the data in [13]) to be fully precipitated at approximately $0.2 \mathrm{mM}$ free $\mathrm{Mg}^{2+}$, hinting that $\operatorname{Ins}(1,3,4,5,6) P_{5}$ might have been selected for its function in erythrocytes partly as a consequence of its solubility in the presence of $\mathrm{Mg}^{2+}$.

Biological predictions for $\operatorname{Ins}(1,3,4,5,6) P_{5}$ under extracellular conditions

It is relevant to predict the speciation of $\operatorname{Ins}(1,3,4,5,6) P_{5}$ under high- $\mathrm{Ca}^{2+}$, high- $\mathrm{Mg}^{2+}$ conditions such as those prevalent in the extracellular medium of mammals because (1) such conditions correspond to those experiments in which the compound is added to culture cells in physiological media and (2) concentrations of inositol pentakisphosphates in the 10-20-nM range have been reported for rat plasma [42] (although the accompanying measurements for Ins $P_{6}$ have been questioned [43]). We therefore chose $150 \mathrm{mM} \mathrm{Na}^{+}, \mathrm{pH} 7.5,2 \mathrm{mM}$ total $\mathrm{Ca}^{2+}$ and $2 \mathrm{mM}$ total $\mathrm{Mg}^{2+}$ to simulate extracellular-like conditions. We first ran a simulation with $\operatorname{Ins}(1,3,4,5,6) P_{5}$ at $15 \mathrm{nM}$, i.e. a concentration similar to that reported by Grases et al. [42]: the result shows that plasma Ins $(1,3,4,5,6) P_{5}$, if present in the reported concentration range and not bound to proteins, would exist predominantly as a soluble mixture of soluble $\left[\mathrm{Ca}_{4}\left(\mathrm{H}_{2} \mathrm{~L}\right)\right](93 \%)$ and $\left[\mathrm{Mg}_{4}\left(\mathrm{H}_{2} \mathrm{~L}\right)\right](6 \%)$. We then ran simulations with increasing amounts of $\operatorname{Ins}(1,3,4,5,6) P_{5}$, so as to determine its maximum solubility in plasma: under the conditions detailed above, $60-65 \mu \mathrm{M} \operatorname{Ins}(1,3,4,5,6) P_{5}$ can exist in solution, mostly as the mixture $\left[\mathrm{Mg}_{4}\left(\mathrm{H}_{2} \mathrm{~L}\right)\right] /$ $\left[\mathrm{Ca}_{4}\left(\mathrm{H}_{2} \mathrm{~L}\right)\right]$. The solubility in intracellular vesicular compartments, similarly rich in $\mathrm{Ca}^{2+}$ and $\mathrm{Mg}^{2+}$ as the extracellular medium but more acidic, will be in excess of the value given above. Therefore, the physicochemical properties of Ins $(1,3,4,5,6) P_{5}$ would allow the existence of a significant pool of soluble, protein-free compound in the extracellular medium as well as in intracellular vesicular compartments.

Practical data for the experimentation with $\operatorname{Ins}(1,3,4,5,6) P_{5}$

Our data provide a few simple guidelines to keep experiments using added $\operatorname{Ins}(1,3,4,5,6) P_{5}$ within reasonably physiological conditions. When mimicking cytosolic/ nuclear conditions, one must reason that $\operatorname{Ins}(1,3,4,5,6) P_{5}$ can complex up to $4 \mathrm{~mol}$ of $\mathrm{Mg}^{2+}$ per mole, although under most conditions except for very large $\mathrm{Mg}^{2+}$ excesses and/or very high $\mathrm{pH}$, this will be less than 1 mol per mole (see, e.g., Table 3). Since cytosol and nucleus of mammalian cells contain $0.25-1 \mathrm{mM}$ free $\mathrm{Mg}^{2+}$ [32], the total concentration of $\mathrm{Mg}^{2+}$ included in the experiments must be in excess of the molar concentration of $\operatorname{Ins}(1,3,4,5,6) P_{5}$ (plus the $\mathrm{Mg}^{2+}$-complexating capacity of any other chelators such as ATP that are present). Under these conditions Ins $(1,3,4,5,6) P_{5}$ will remain in solution up to $135 \mu \mathrm{M}$ (or 

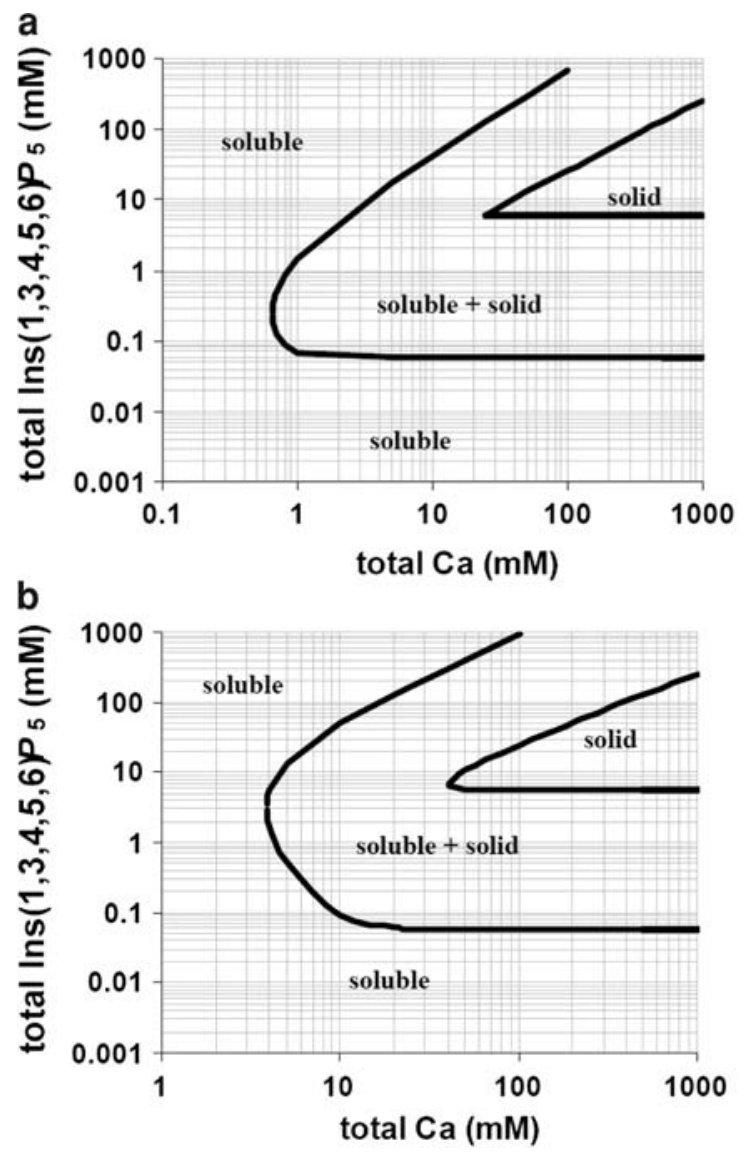

Fig. 9 The solubility behaviour of $\operatorname{Ins}(1,3,4,5,6) P_{5}$, as predicted by the equilibrium equations, in the presence of $\mathrm{Ca}^{2+}[\mathbf{a}(\mathrm{Ca}, \mathrm{pH} 7.5)$, b $(\mathrm{Ca}, \mathrm{pH} 5.0)]$ or $\mathrm{Mg}^{2+}[\mathbf{c}(\mathrm{Mg}, \mathrm{pH} 7.5), \mathbf{d}(\mathrm{Mg}, \mathrm{pH}$ 5.0)] plotted for

higher, but this only for a very restricted subset of conditions).

For procedures involving other conditions (e.g. the preparation of stock solutions, experiments mimicking intestinal conditions, assays of enzymatic activities with biotechnological purposes), a very important practical point is to know in advance whether $\operatorname{Ins}(1,3,4,5,6) P_{5}$ will be soluble or will precipitate. The solubility of Ins $(1,3,4,5,6) P_{5}$ is determined by multiple linked equilibria (solid formation as such plus the various complexation and protonation equilibria in solution), and hence the constants reported in this paper can only be put into practice with the help of a specialized software program such as HySS. We have thus put together a series of plots that summarize the solubility behaviour of $\operatorname{Ins}(1,3,4,5,6) P_{5}$ in the presence of $\mathrm{Ca}^{2+}$ and $\mathrm{Mg}^{2+}$ (Fig. 9). In these plots, the frontiers between solubility and precipitation are given in terms of total concentrations of Ins $(1,3,4,5,6) P_{5}$ and metal. Overall, for each given condition, the area of dominance of the solids is wedged in the plots within the region of full solubility, which encompasses both low and high
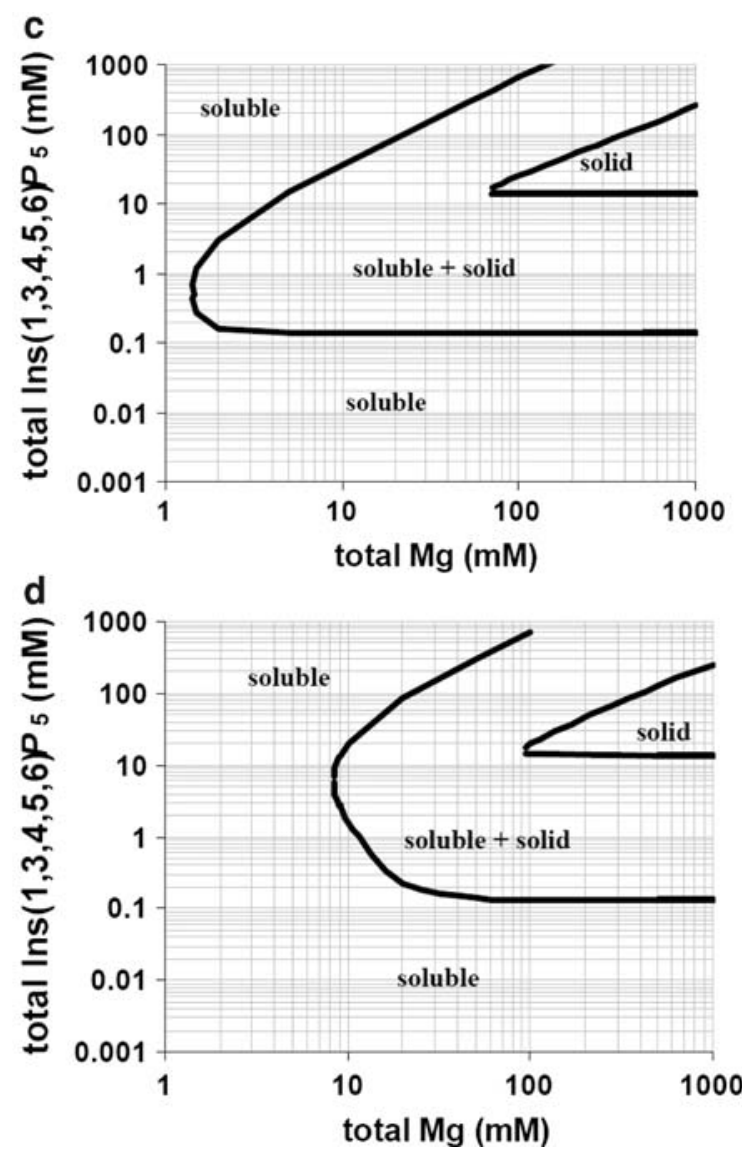

$\mathrm{pH} 7.5$ and 5.0. The "frontier lines" drawn correspond to conditions in which either $1 \%$ or $99 \%$ of $\operatorname{Ins}(1,3,4,5,6) P_{5}$ present is predicted to exist as a solid

Ins $(1,3,4,5,6) P_{5}$ concentrations. As mentioned before, the subregions of low and high Ins $(1,3,4,5,6) P_{5}$ concentration are dominated by $4: 1$ and the $1: 1$ complexes, respectively. The "wedges" of precipitation in the plots have mostly "horizontal" "lower boundaries", which correspond to the fixed values for the solubility of the $\left[\mathrm{M}_{4}\left(\mathrm{H}_{2} \mathrm{~L}\right)\right]$ complexes mentioned above. However, these "horizontal boundaries" do not apply in the low metal concentration range (below $5 \mathrm{mM} \mathrm{M}^{2+}$ for $\mathrm{pH} 7.5$; below $20 \mathrm{mM} \mathrm{Ca}^{2+}$ or $60 \mathrm{mM} \mathrm{Mg}^{2+}$ for $\mathrm{pH} 5.0$ ), in which the $1: 1$ complexes become increasingly significant and add to the total solubility of Ins $(1,3,4,5,6) P_{5}$. In fact, going towards low $\mathrm{M}^{2+}$ concentrations, one reaches a value below which Ins $(1,3,4,5,6) P_{5}$, irrespective of its concentration, does not precipitate as $\mathrm{Ca}^{2+}$ or $\mathrm{Mg}^{2+}$ salt; these values are $0.65 \mathrm{mM}$ for $\mathrm{Ca}^{2+}$ and $1.37 \mathrm{mM}$ for $\mathrm{Mg}^{2+}$ at $\mathrm{pH} 7.5$, and increase substantially as the $\mathrm{pH}$ is lowered. It must be borne in mind that while the plots in Fig. 9 are given in terms of total metal ion, for some purposes what is known and/or fixed is the concentration of free metal ion, as is the case with in vivo experiments. 
Acknowledgments N.V. is indebted to PEDECIBA-Química and ANII for a scholarship. We acknowledge support from the Wellcome Trust (programme grant 082837 to A.M.R. and B.V.L.P.). Thermal analyses were carried out by Jorge Castiglioni, LAFIDESU, DETEMA, Facultad de Química (Uruguay). A.D. is grateful to the Biochemical Society for a bursary to attend the Harden conference on inositol phosphates and lipids.

\section{References}

1. Irvine RF, Schell MJ (2001) Nat Rev Mol Cell Biol 2:327-338

2. Johnson LF, Tate ME (1969) Can J Chem 47:63-73

3. Stephens LR, Hawkins PT, Stanley AF, Moore T, Poyner DR, Morris PJ, Hanley MR, Kay RR, Irvine RF (1991) Biochem J 275:485-499

4. Guse AH, Emmrich F (1991) J Biol Chem 266:24498-24502

5. McConnell FM, Stephens LR, Shears SB (1991) Biochem J 280:323-329

6. Verbsky JW, Wilson MP, Kisseleva MV, Majerus PW, Wente SR (2002) J Biol Chem 277:31857-31862

7. Shears SB (2007) Biochem Soc Symp 74:211-221

8. Frederick JP, Mattiske D, Wofford JA, Megosh LC, Drake LY, Chiou ST, Hogan BL, York JD (2005) Proc Natl Acad Sci USA 102:8454-8459

9. Komander D, Fairservice A, Deak M, Kular GS, Prescott AR, Peter Downes C, Safrany ST, Alessi DR, van Aalten DM (2004) EMBO J 23:3918-3928

10. Jackson SG, Zhang Y, Haslam RJ, Junop MS (2007) BMC Struct Biol 7:80-90

11. Gao Y, Wang HY (2007) J Biol Chem 282:26490-26502

12. Shears SB (2001) Cell Signal 13:151-158

13. Veiga N, Torres J, Domínguez S, Mederos A, Irvine RF, Díaz A, Kremer C (2006) J Inorg Biochem 100:1800-1810

14. Torres J, Domínguez S, Cerdá MF, Obal G, Mederos A, Irvine RF, Díaz A, Kremer C (2005) J Inorg Biochem 99:828-840

15. Torres J, Veiga N, Gancheff J, Domínguez S, Mederos A, Sundberg M, Sánchez A, Castiglioni J, Díaz A, Kremer C (2008) J Mol Struct 874:77-88

16. Veiga N, Torres J, Mansell D, Freeman S, Domínguez S, Barker CJ, Díaz A, Kremer C (2009) J Biol Inorg Chem 14:51-59

17. Schwarzenwach G, Flaschka H (1969) Complexometric titrations, 2nd edn. Methuen, London

18. Godage HY, Riley AM, Woodman TJ, Potter BVL (2006) Chem Commun 2989-2991

19. Gans P, O’Sullivan B (2000) Talanta 51:33-37

20. Gans P, Sabatini A, Vacca A (1996) Talanta 43:1739-1753
21. Alderighi L, Gans P, Ienco A, Peters D, Sabatini A, Vacca A (1999) Coord Chem Rev 184:311-318

22. Riley AM, Trusselle M, Kuad P, Borkovec M, Cho J, Choi JH, Qian X, Shears SB, Spiess B, Potter BVL (2006) Chembiochem 7:1114-1122

23. Mansell D, Rattray N, Etchells L, Schwalbe CH, Blake AJ, Bichenkova EV, Bryce R, Barjer CJ, Díaz A, Kremer C, Freeman S (2008) Chem Commun 5161-5163

24. Hawkins PT, Poyner DR, Jackson TR, Letcher AJ, Lander DA, Irvine RF (1993) Biochem J 294:929-934

25. Spiers ID, Barker CJ, Chung S-K, Chang Y-T, Freeman S, Gardiner JM, Hirst PH, Lambert PA, Michell RH, Poyner DR, Schwalbe CH, Smitn AW, Solomons KRH (1996) Carbohydr Res 282:81-99

26. Stuart JA, Anderson KL, French PJ, Kirk CJ, Michell RH (1994) Biochem J 303:517-525

27. Miller AL, Suntharalingam M, Johnson SL, Audhya A, Emr SD, Wente SR (2004) J Biol Chem 279:51022-51032

28. French PJ, Bunce CM, Stephens LR, Lord JM, McConell FM, Brown G, Creba JA, Michell RH (1991) Proc R Soc Lond B 245:193-201

29. Bunce CM, French PJ, Allen P, Mountford JC, Moor B, Greaves MF, Michell RH, Brown G (1993) Biochem J 289:667-673

30. Barker CJ, Wright J, Hughes PJ, Kirk CJ, Michell RH (2004) Biochem J 380:465-473

31. Wu MM, Llopis J, Adams JM, McCaffery MS, Kulomaa TE, Machen TE, Moore HP, Tsien RY (2000) Chem Biol 7:197-209

32. Grubbs RD (2002) Biometals 15:251-259

33. Kakhlon O, Kabantch I (2002) Free Radic Biol Med 33:10371046

34. Isbrandt LR, Oertel RP (1980) J Am Chem Soc 102:3144-3148

35. Chapman AC, Thirlwell LE (1964) Spectrochim Acta 20:937947

36. Rajkumar BJM, Ramakrishnan V (2001) Spectrochim Acta A $57: 247-254$

37. Lin-Vien D, Colthup NB, Fateley WG, Graselli JG (1991) The handbook of infrared and Raman characteristic frequencies of organic molecules. Academic Press, San Diego

38. He Z, Honeycutt CW, Zhang T, Bertsch PM (2006) J Environ Qual 35:1319-1328

39. Bartlett GR (1976) Comp Biochem Physiol A 55:211-214

40. Villar JL, Puigbò P, Riera-Codina M (2003) Comp Biochem Physiol B 135:169-175

41. Günther T (2007) Magnes Res 20:161-167

42. Grases F, Simonet BM, Prieto RM, March JG (2001) J Nutr Biochem 12:595-601

43. Letcher AJ, Schell MJ, Irvine RF (2008) Biochem J 416:263-270 